\title{
PERANCANGAN SISTEM INFORMASI MANAJEMEN PERPUSTAKAAN MENGGUNAKAN POLA MODEL-VIEW- CONTROLLER (MVC)
}

\author{
Rangga Sanjaya \\ Fakultas Teknik, Universitas BSI \\ Jalan Sekolah Internasional No. 1-6, Bandung 40282, Indonesia \\ rangga.rsj@bsi.ac.id
}

\begin{abstract}
Systems based on information technology has revolutionized almost every aspect of an organization's business processes. Information technology has improved the access processes of information by integrating information across data sources. Website is one of the popular information technology. Website by using the Model-ViewController (MVC) pattern, gives quality to the process of development and management access of information resources. Features on the website were built very useful for libraries management processes, transactions, and accounting information.
\end{abstract}

Keywords: Management, Information, System, Library, Website, MVC

Abstraksi - Sistem berbasis teknologi informasi telah merevolusi hampir setiap aspek dari proses bisnis organisasi. Teknologi informasi meningkatkan proses akses informasi dengan mengintegrasikan informasi dari seluruh sumber data. Website merupakan salah satu teknologi informasi yang populer. Website dengan menggunakan pola Model-ViewController (MVC), memberikan kualitas proses pembangunan dan akses pengelolaan sumber daya informasi. Fitur pada situs web yang dibangun sangat berguna untuk proses manajemen, transaksi, dan informasi akuntansi perpustakaan.

Kata Kunci: Manajemen, Sistem, Informasi, Perpustakaan, Website, MVC

\section{PENDAHULUAN}

Perkembangan perpustakaan pada era masyarakat informasi telah dimanfaatkan sebagai salah satu pusat informasi, sumber ilmu pengetahuan, penelitian, rekreasi, dan pelestarian khasanah ilmu pengetahuan (Pebrianto, 2012). Dalam menunjang aktivitas perpustakaan, diperlukan suatu pengelolaan perpustakaan seperti data pustaka, staf, anggota, transaksi peminjaman, pengadaan, kehilangan, transaksi keuangan, dan pelaporan. Dengan adanya manajemen yang baik, maka perpustakaan dapat memberikan layanan yang optimal kepada pengguna perpustakaan.

Teknologi informasi saat ini menjadi bagian penting dalam suksesnya proses bisnis organisasi. Teknologi informasi digunakan untuk komunikasi dan mengelola sumber informasi sehingga dapat meningkatkan performa bisnis perusahaan. Teknologi informasi dapat meningkatkan penyampaian informasi, pengambilan keputusan, koordinasi, kualitas informasi, daya tanggap, dan distribusi (Malone $(1987,1989)$, Guarbaxani \& Wang dalam Siahaan, 2013).

Website merupakan teknologi informasi yang bersifat multi platform dan dapat bekerja optimal dalam suatu jaringan. Keberadaan website memicu metode baru dalam mengakses dan mengelola sumber informasi secara efektif dan efisien. Pengguna dapat terhubung ke sumber informasi dalam jaringan internet maupun intranet, sehingga memungkinkan jarak akses yang lebih luas. Dengan dukungan 
teknologi yang multi platform, website dapat diakses dari berbagai media dan sistem operasi sehingga sumber daya organisasi dapat digunakan dengan optimal.

Dilihat dari tingkat fleksibilitas yang ditawarkan oleh teknologi website, maka pembangunan sistem informasi manajemen perpustakaan dapat dikembangkan dengan menggunakan pola Model-View-Controller (MVC). MVC merupakan sebuah metode untuk membuat sebuah aplikasi dengan memisahkan data (model), tampilan (view) dan cara bagaimana memprosesnya (controller) (Radek dalam Muzakir, 2014). Maka dari itu, MVC memungkinkan pengembangan perangkat lunak yang besar dapat dibagi kedalam kasus-kasus yang lebih kecil, sehingga memudahkan dalam pembagian tugas, perbaikan, penambahan, dan dokumentasi perangkat lunak yang lebih baik.

\section{METODE PENELITIAN}

Metode penelitian yang digunakan dalam penelitian ini adalah metode penelitian eksperimen. Metode eksperimen ini digabungkan dengan metode pengembangan sistem model incremental. Model incremental membagi pengembangan perangkat lunak kedalam pengembangan komponen yang lebih kecil, kemudian komponen tersebut diintegrasikan dalam setiap pengulangan pengembangan dan diuji secara keseluruhan (Pressman, 2001). Berikut adalah tahapan yang dilakukan dalam penelitian ini seperti yang terlihat pada Gambar 1.

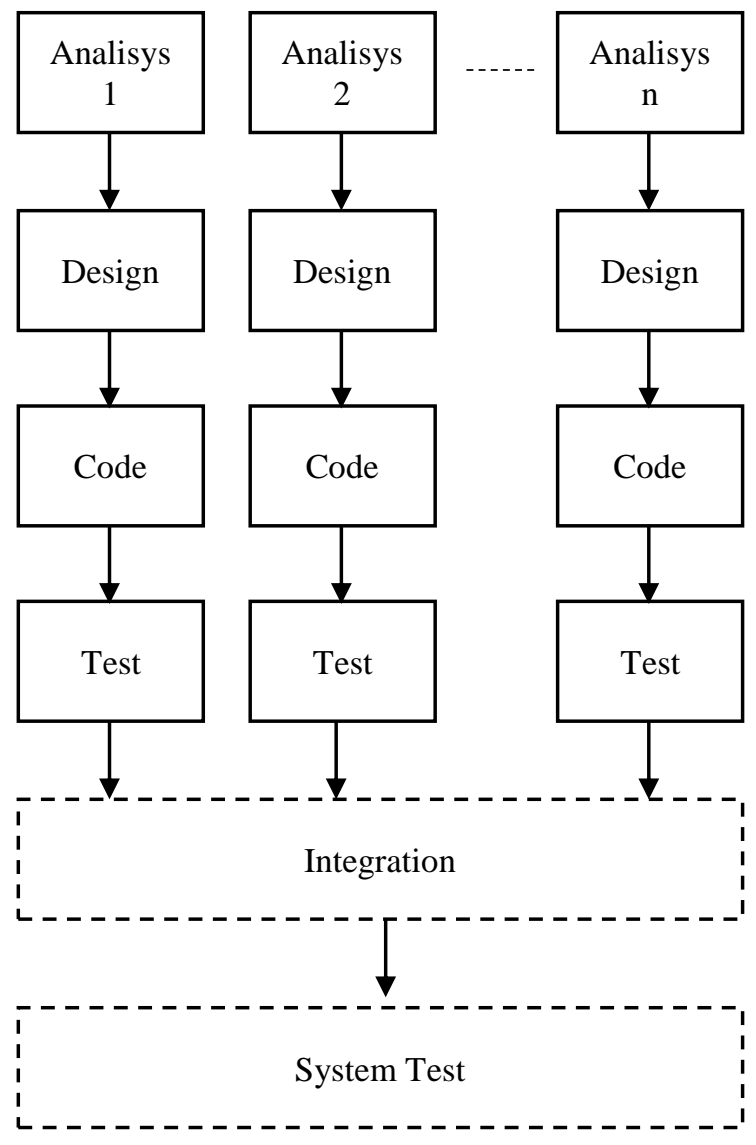

Gambar 1

Model Pengembangan Perangkat Lunak 


\section{Analisys}

Melakukan pengumpulan data yang akan digunakan sebagai kebutuhan pada tahap design. Metode pengumpulan data yang digunakan dalam penelitian ini, adalah sebagai berikut:

a. Pengumpulan data lapangan di beberapa perpustakaan yang akan digunakan dalam melakukan pengujian.

b. Melakukan wawancara secara langsung kepada staf dan pengguna layanan perpustakaan terkait apa yang dilakukan dan yang diharapkan pada sisi pelayanan dengan pendekatan teknologi informasi. c. Melakukan penyebaran kuisioner untuk memperoleh masukan terkait pengembangan sistem.

d. Studi kepustakaan, menggunakan literatur yang relevan berupa buku, conference paper, jurnal, proceeding, dan website internet terkait dengan informasi yang dibutuhkan.

2. Design

Membuat rancangan perangkat lunak yang akan diimplementasikan pada tahap code. Desain sistem secara umum pada setiap komponen menggunakan pola MVC seperti yang terlihat pada gambar 2.

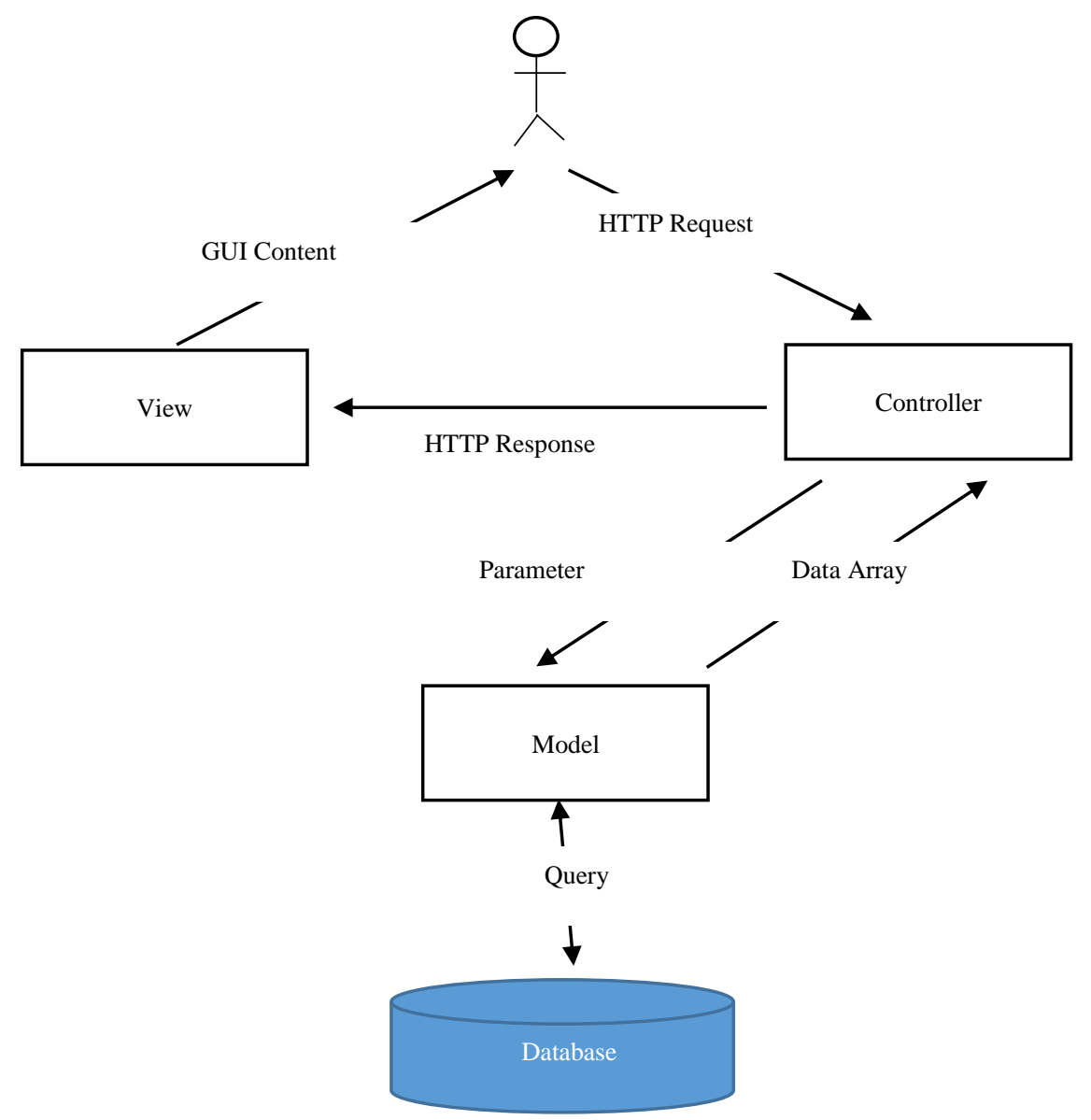

Gambar 2

Desain MVC 
Berikut adalah masing-masing tugas dari setiap bagian MVC:

a. Model merupakan bagian yang berfungsi untuk melakukan akses ke database.

b. View merupakan user interface yang secara langsung berinteraksi dengan user.

c. Controller merupakan bagian yang memproses permintaan dari user.

Dokumentasi rancangan sistem secara lebih rinci menggunakan pendekatan desain dan analisis berorientasi objek dengan menggunakan notasi Unified Modeling Language (UML).

\section{Code}

Mengimplementasikan rancangan sistem ke dalam kode program menggunakan pemrograman PHP dengan framework Yii2. Yii merupakan framework pengembangan aplikasi website yang bersifat open-source yang ditulis dalam PHP5 (Yii Software, 2015).

\section{Test}

$$
\text { Pengujian dilakukan untuk }
$$
mengidentifikasi sistem yang dikembangkan sesuai dengan analisis dan rancangan sistem. Pengujian sistem yang dilakukan terdiri dari pengujian black box dan pengujian tingkat kepuasan user. Pengujian black box dilakukan dengan menjalankan setiap unit kemudian diamati kesesuaian dengan rancangan sistem. Pengujian tingkat kepuasan user dilakukan terhadap masing-masing tipe pengguna dari aplikasi yang dibangun.

\section{PEMBAHASAN}

Dari hasil eksperimen yang dilakukan berdasarkan metode penelitian, diperoleh prototipe sistem informasi manajemen perpustakaan berbasis website sebagai berikut:

\section{Analisis kebutuhan user}

Actor yang diidentifikasi pada prototipe aplikasi yang dibangun adalah sebagai berikut:

a. Staf Perpustakaan

1) Mengelola data pustaka.

2) Mencatat pengadaan buku dari berbagai sumber, seperti pembelian, sumbangan, kerjasama.

3) Mengelola data anggota, seperti registrasi, dan perpanjangan anggota.

4) Mengelola data staf, seperti tambah dan edit data staf.

5) Pengaturan administrasi pinjaman berdasarkan tipe anggota, diantaranya denda, biaya registrasi, dan lama pinjam.

6) Mencatat transaksi peminjaman buku.

7) Mencatat transaksi pengembalian buku.

8) Mencatat transaksi buku keluar, seperti hilang, rusak, dan lainlain.

9) Mencatat transaksi kas masuk dan kas keluar.

10) Melihat laporan aktivitas perpustakaan.

b. Pengunjung

1) Cari pustaka

2) Isi buku tamu

Dari hasil analisis kebutuhan, dibuat use case diagram seperti yang dapat dilihat pada Gambar 3. 


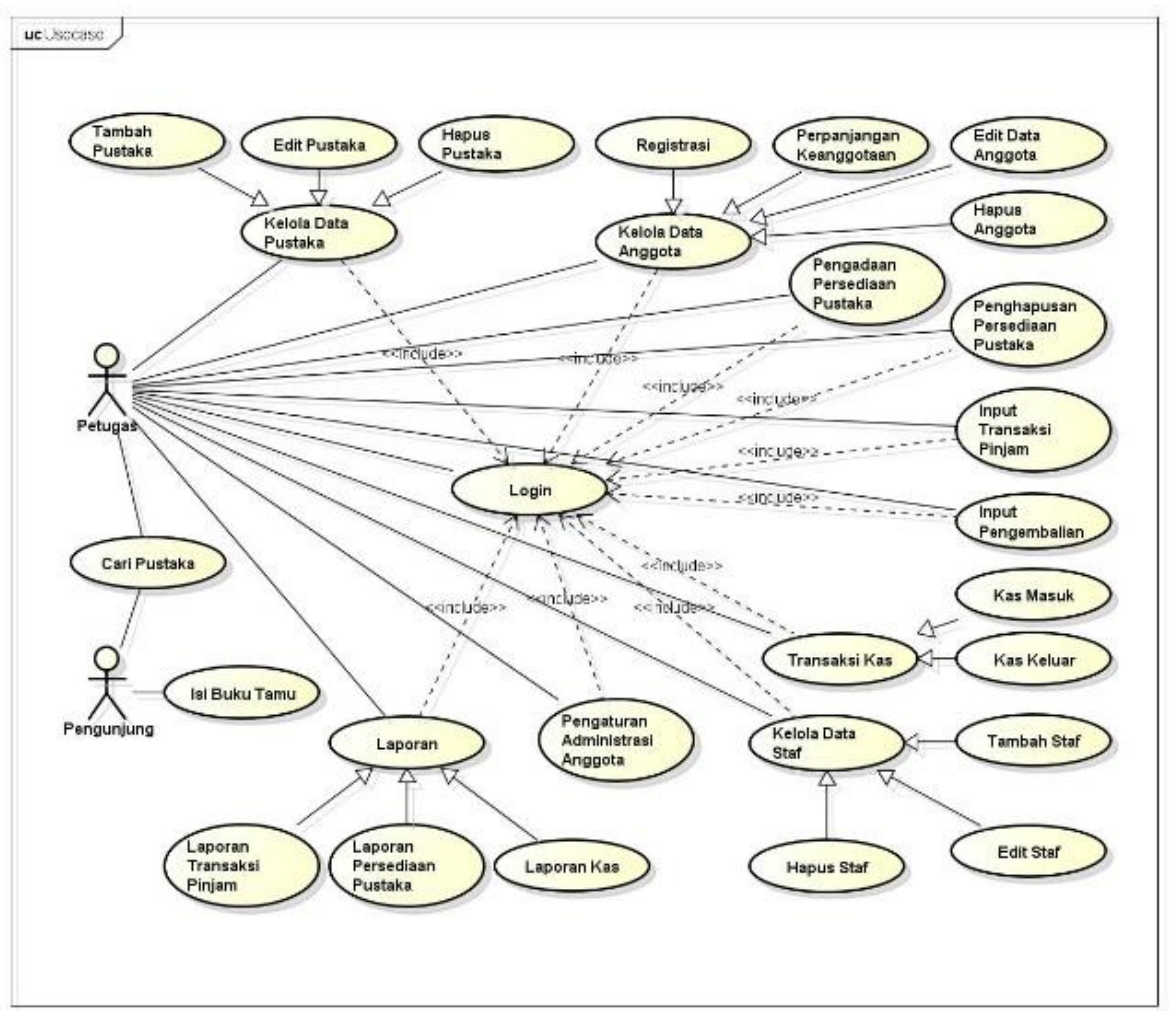

Gambar 3

Use Case Diagram

\section{Class Diagram}

Berdasarkan hasil analisa kebutuhan, kemudian dirancang class diagram seperti yang dapat dilihat pada Gambar 4 yang digunakan untuk menggambarkan struktur sistem dari aplikasi yang akan dibangun.

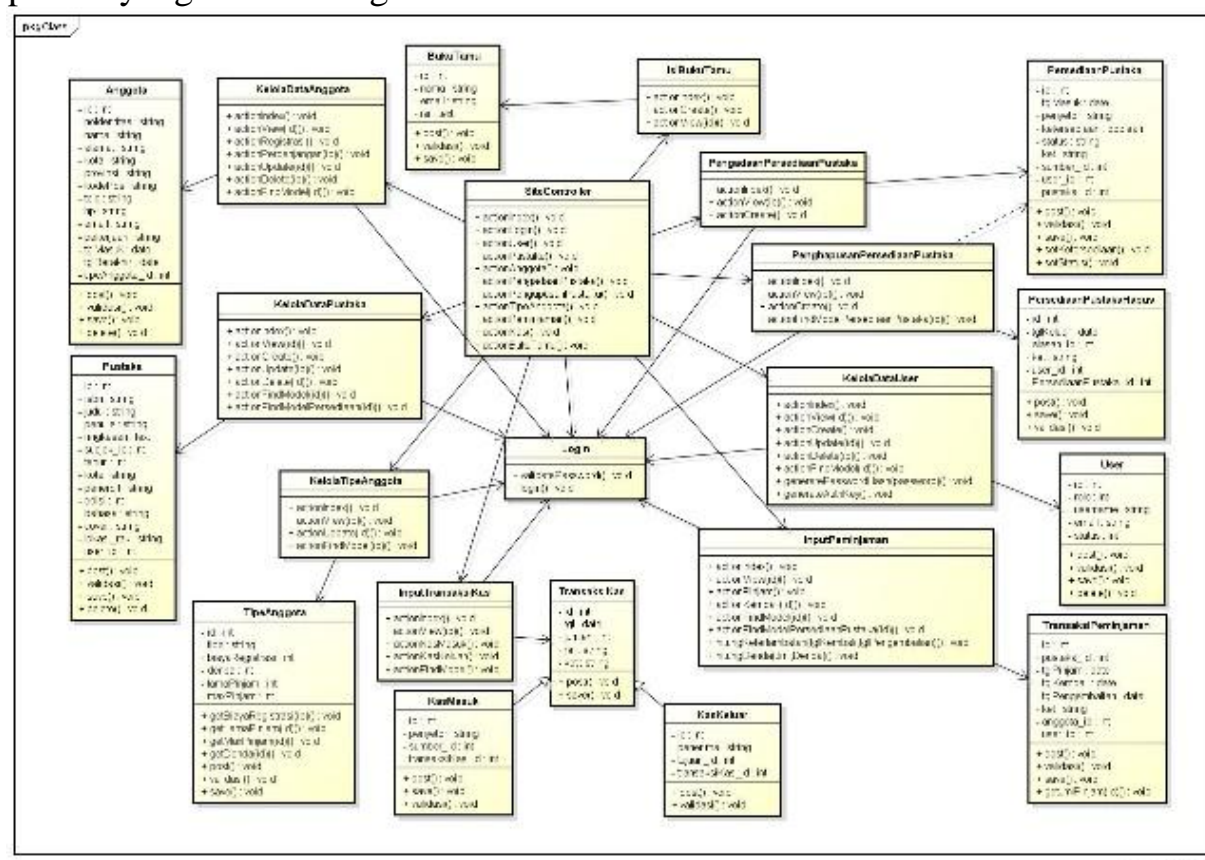

Gambar 4

Class Diagram 
Pada Class diagram yang dirancang, terdapat 2 (dua) kelompok class yang berfungsi sebagai class control dan class model. Class control digunakan untuk mengelola operasi atau fungsi dan pemanggilan view atau interface aplikasi. Sedangkan, class model digunakan untuk mengelola aktivitas terhadap database.

\section{Sequence Diagram}

Rancangan sequence diagram digunakan untuk melihat alur operasi masing-masing use case berdasarkan rancangan class diagram, yang akan diimplementasikan pada tahap coding.
Berikut adalah Sequence Diagram masing-masing use case dari aplikasi yang akan dibangun:

\section{a. Login}

Proses login digunakan untuk validasi hak akses user terhadap operasi yang akan dilakukan. Rancangan urutan proses login dapat dilihat pada Gambar 5.

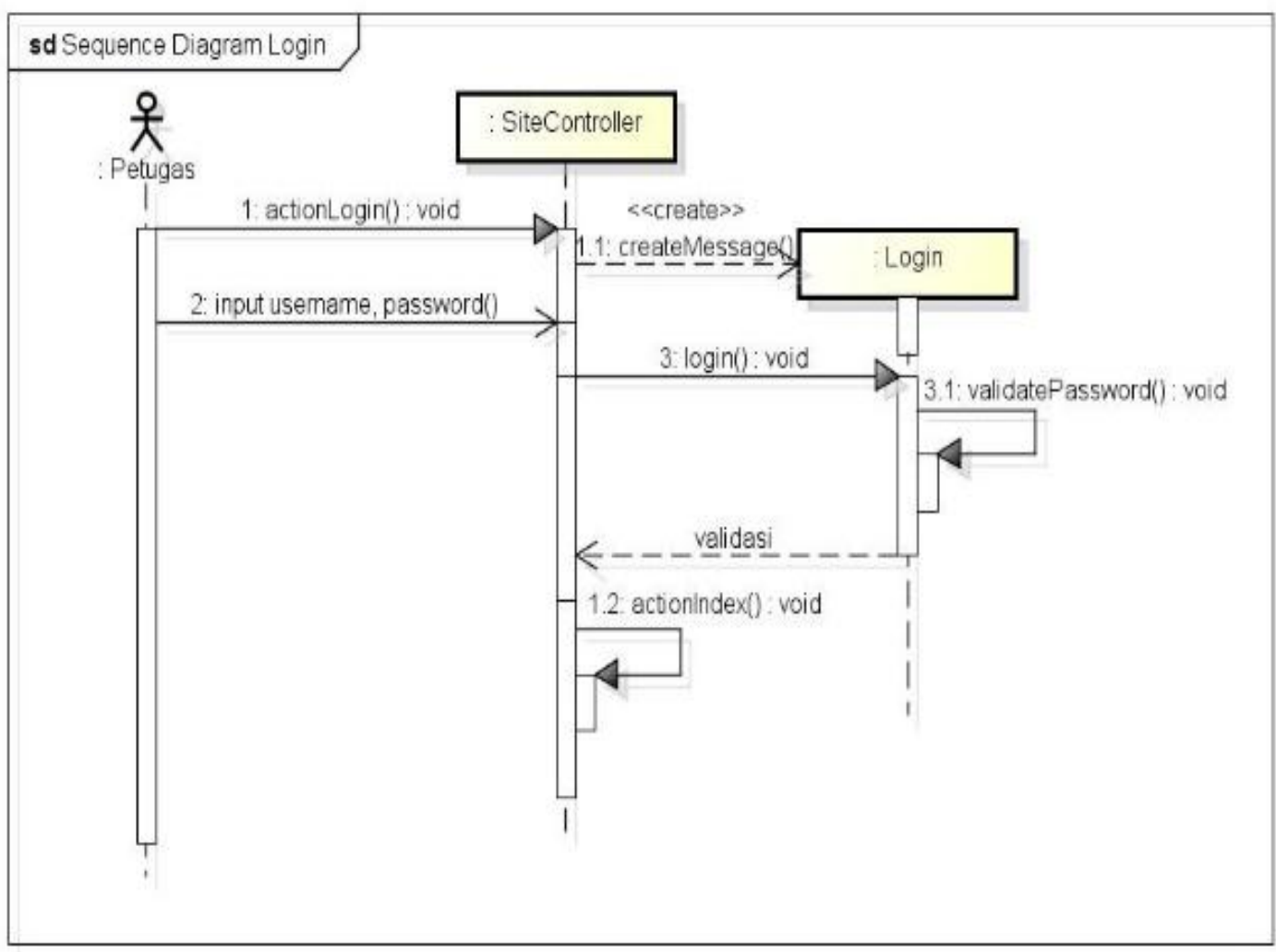

Gambar 5

Sequence Diagram Login 
b. Tambah Pustaka

Proses penambahan pustaka digunakan untuk menambah pustaka per judul yang tersedia di perpustakaan.
Rancangan urutan proses penambahan pustaka dapat dilihat pada Gambar 6.

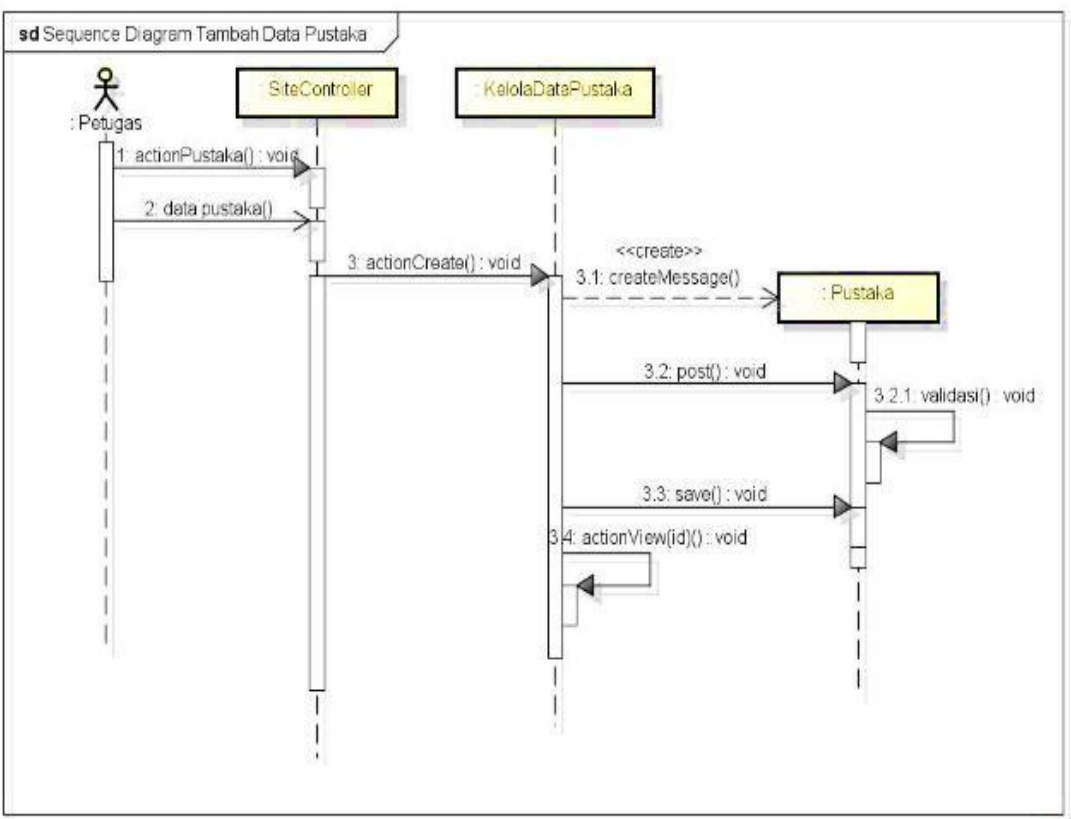

Gambar 6

Sequence Diagram Tambah Pustaka

c. Edit Pustaka

Proses perubahan data pustaka dapat dilakukan pada halaman view data pustaka, kemudian user memilih tombol update. Rancangan urutan proses perubahan data pustaka dapat dilihat pada Gambar 7.

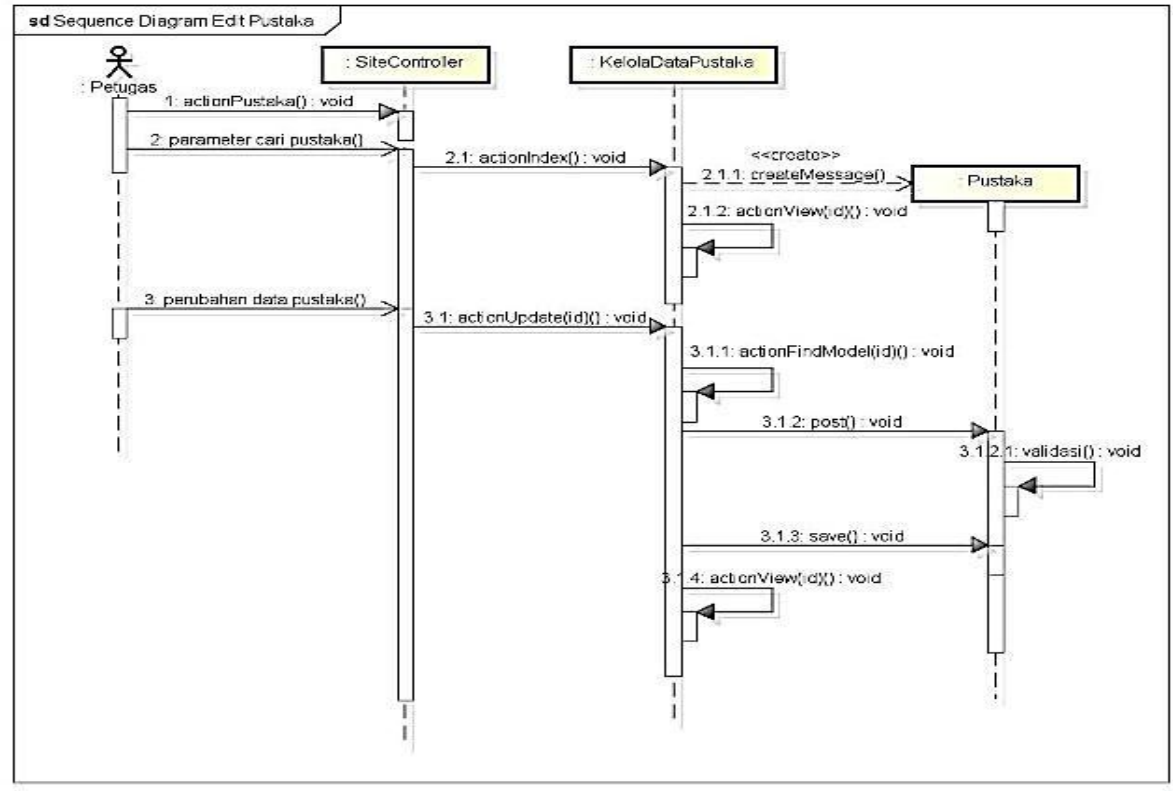

powered by Astah

Gambar 7

Sequence Diagram Edit Pustaka 
d. Hapus Pustaka

Proses menghapus data pustaka hanya dapat dilakukan jika data pustaka tidak pernah digunakan oleh data lain dan juga transaksi pinjam. Rancangan urutan proses menghapus data pustaka dapat dilihat pada Gambar 7.

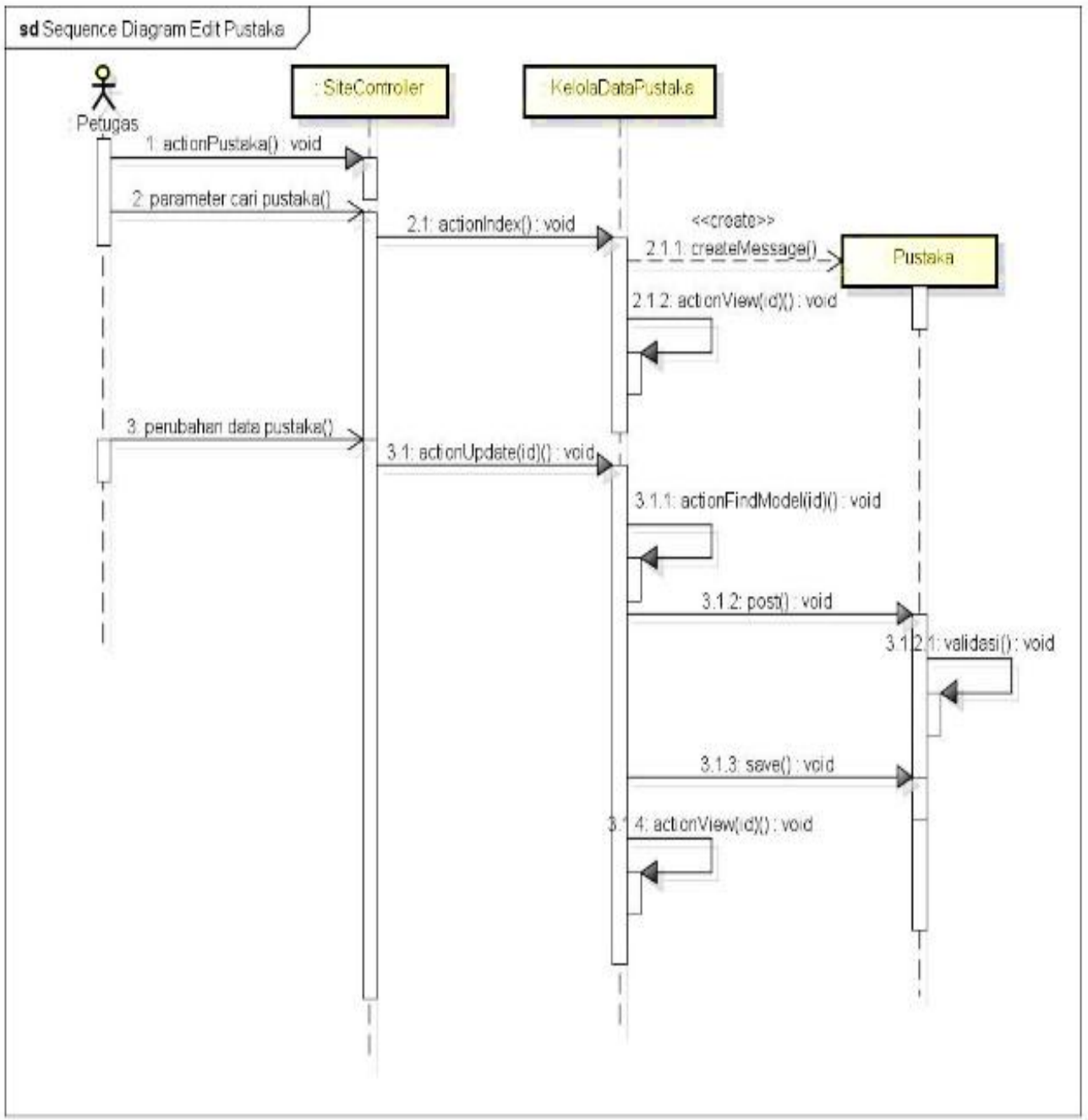

Gambar 8

Sequence Diagram Hapus Pustaka

e. Registrasi Anggota

Proses registrasi anggota digunakan untuk menambah data anggota yang dapat meminjam pustaka perpustakaan. Pada setiap terjadinya proses registrasi, calon anggota akan membayar biaya registrasi sesuai dengan tipe keanggotaan yang didaftarkan. Rancangan urutan proses registrasi anggota dapat dilihat pada Gambar 9. 


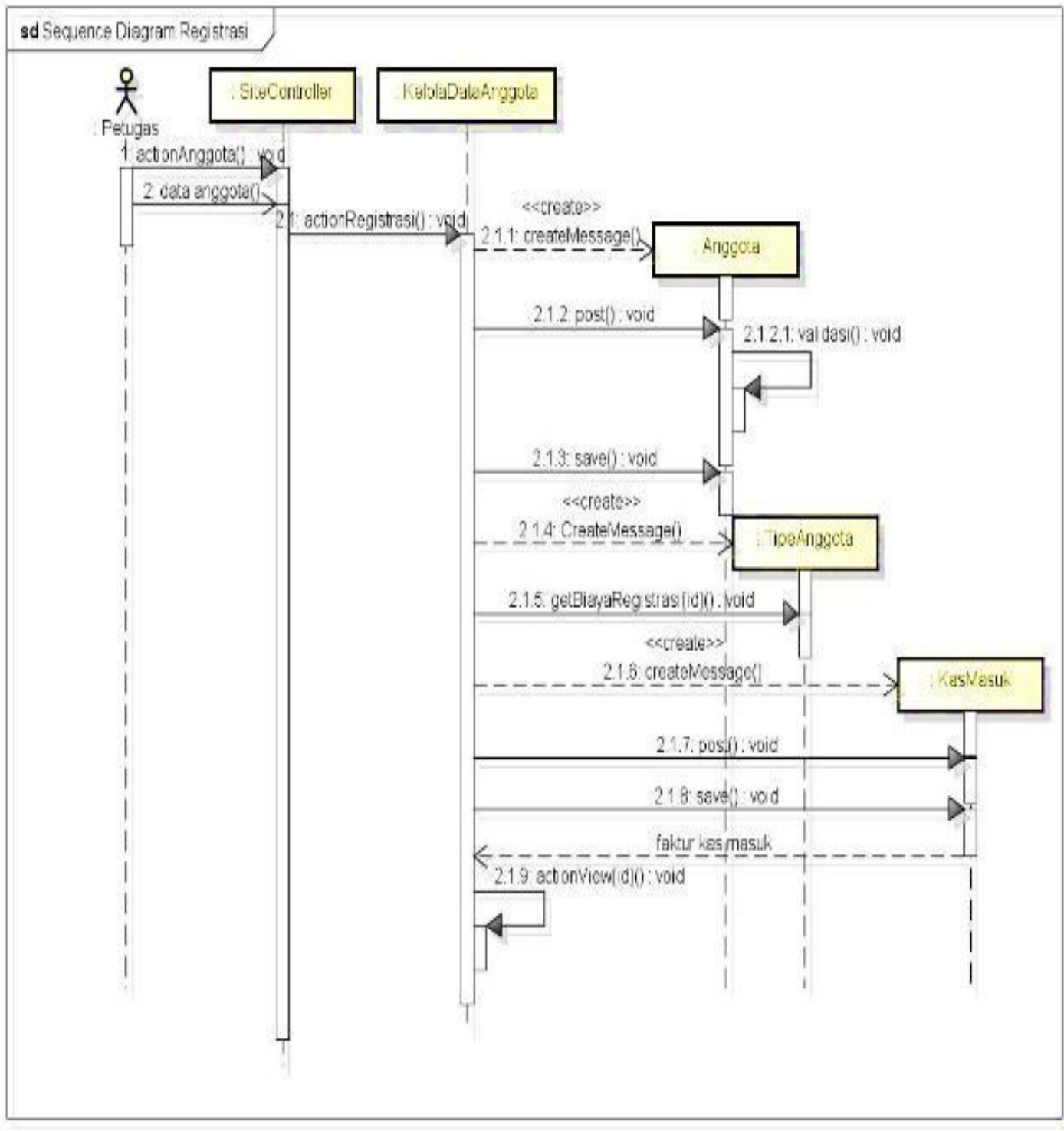

Gambar 9

Sequence Diagram Registrasi Anggota

f. Perpanjangan Keanggotaan Proses memperbaharui tanggal berakhir masa keanggotaan. Pada setiap terjadinya proses perpanjangan keanggotaan, anggota akan membayar biaya registrasi sesuai dengan tipe keanggotaan yang didaftarkan. Rancangan urutan proses perpanjangan keanggotaan dapat dilihat pada Gambar 10. 


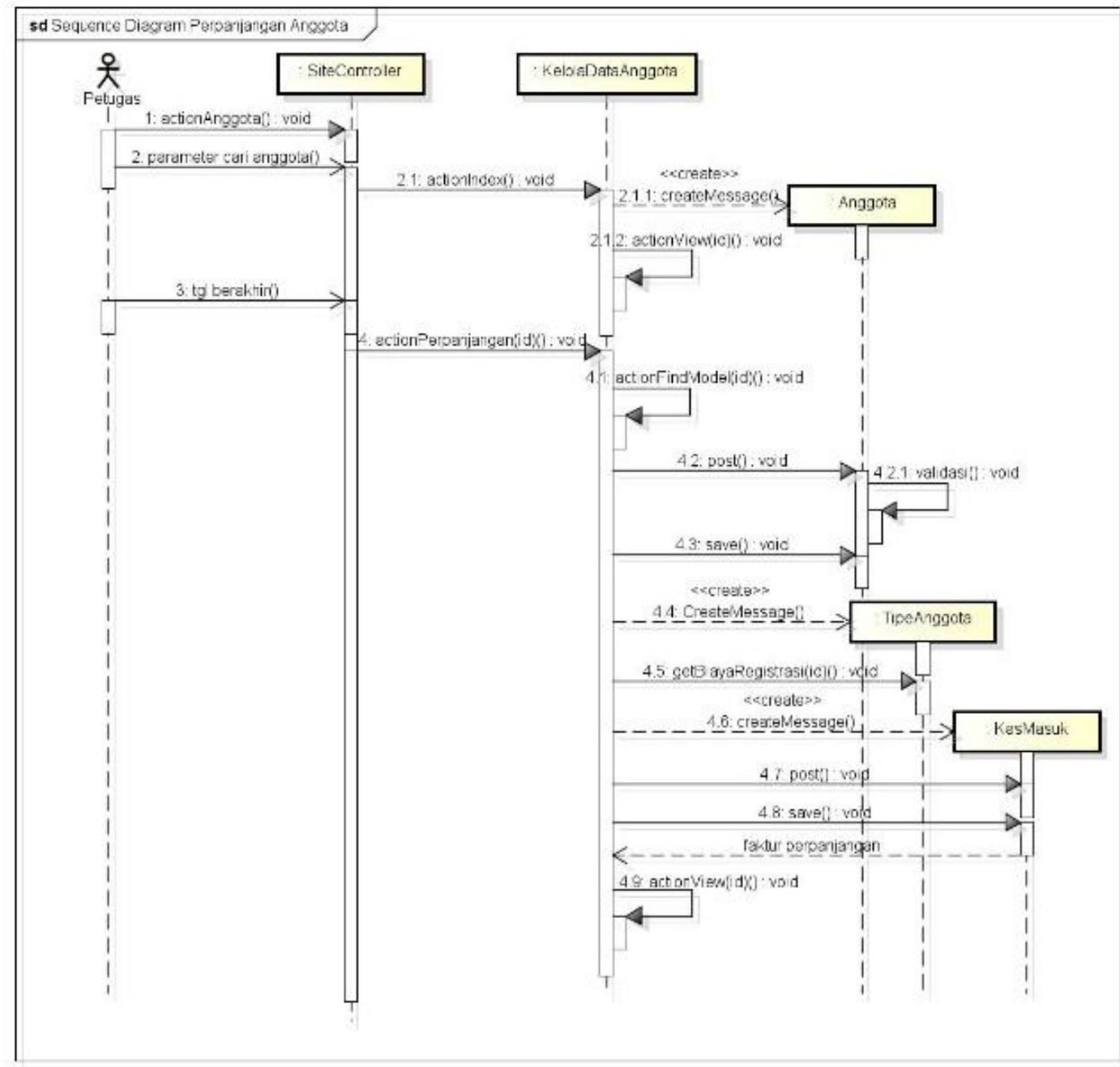

Gambar 10

Sequence Diagram Perpanjangan Keanggotaan

g. Edit Data Anggota

Berbeda dengan proses perpanjangan keanggotaan, proses edit data anggota digunakan untuk merubah data anggota, tetapi tidak dapat memperbaharui tanggal berakhir masa keanggotaan. Rancangan urutan proses perubahan data anggota dapat dilihat pada Gambar 


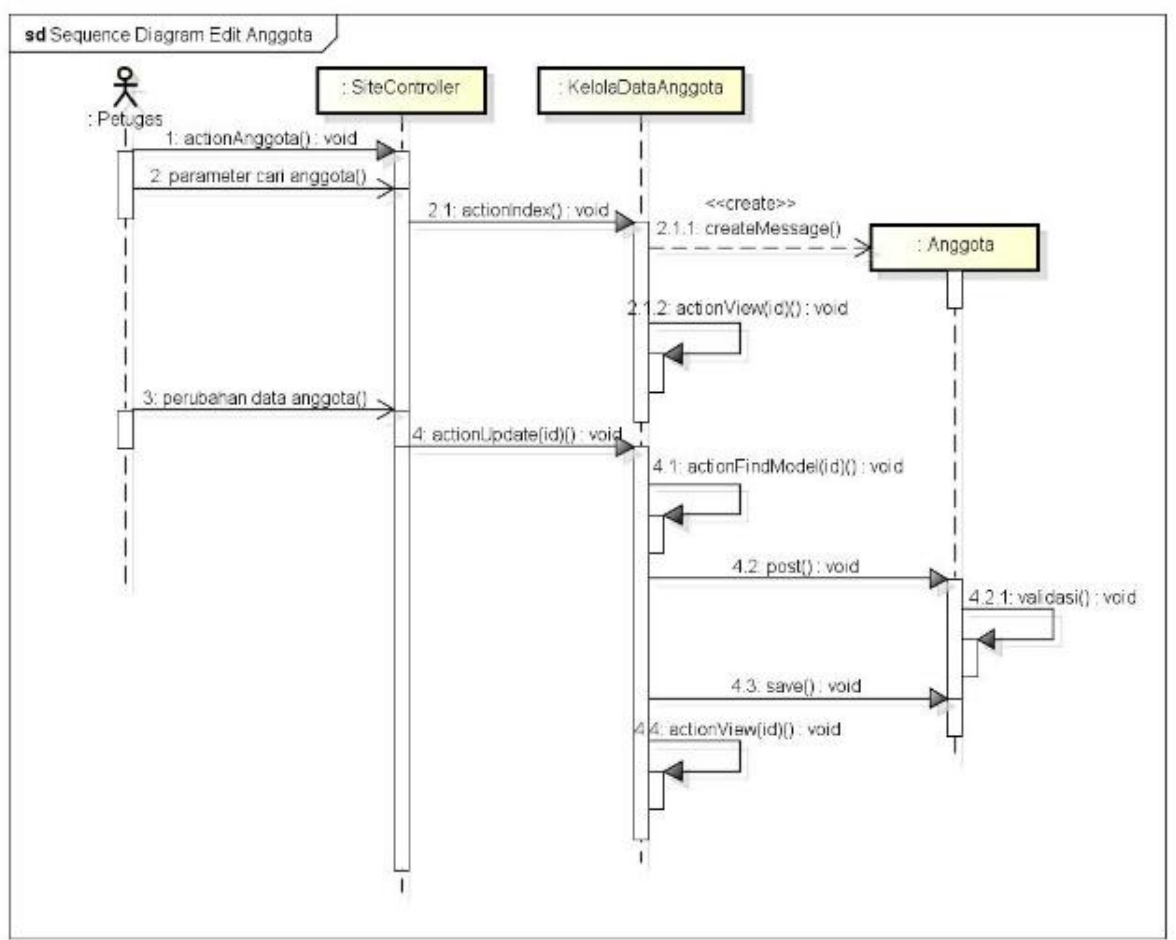

Gambar 11

Sequence Diagram Edit Anggota

h. Hapus Anggota

Proses menghapus data anggota hanya dapat dilakukan jika data anggota tidak pernah digunakan dalam transaksi pinjam. Rancangan urutan proses menghapus data anggota dapat dilihat pada Gambar 12.

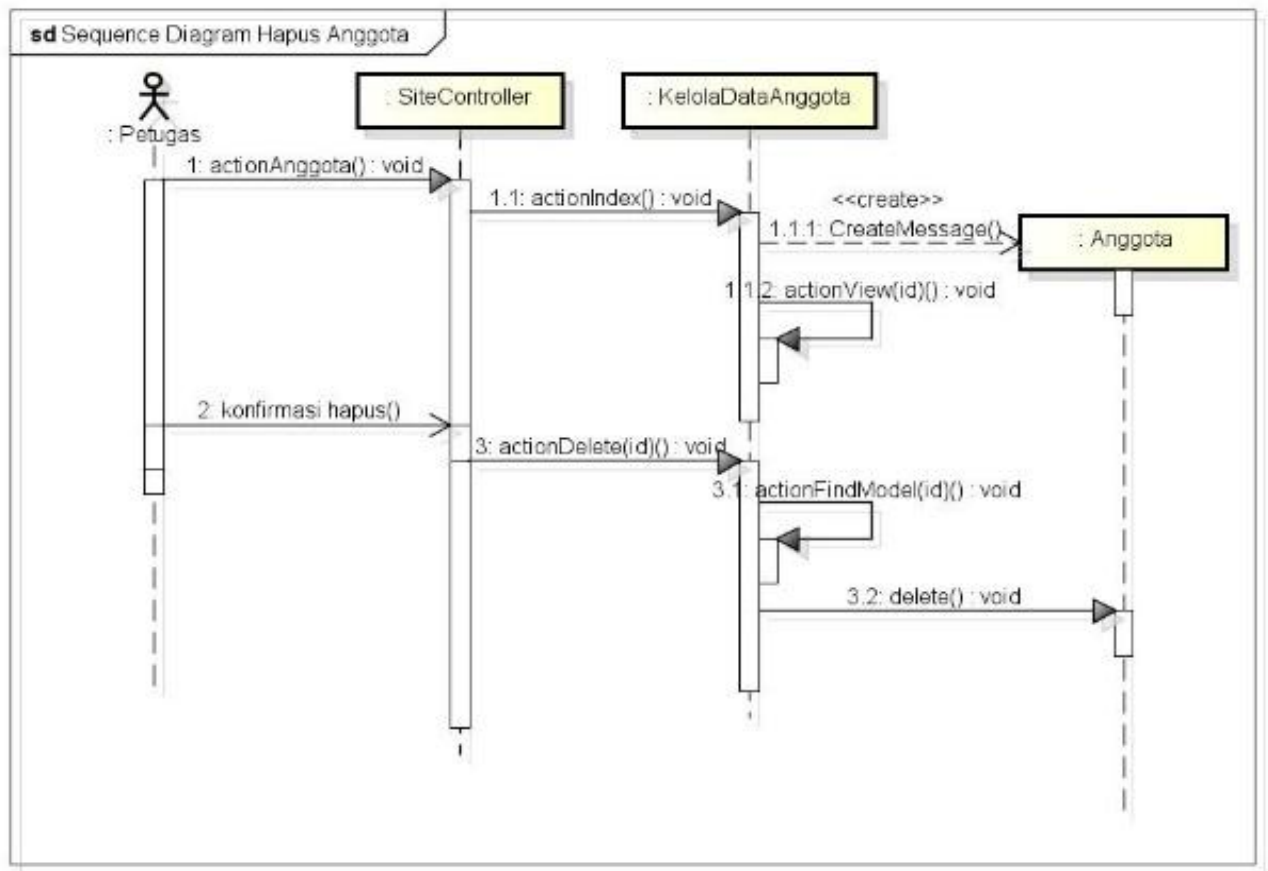

Gambar 12

Sequence Diagram Hapus Anggota 
i. Pengadaan Persediaan Pustaka

Proses pengadaan persediaan pustaka digunakan untuk menambah fisik pustaka yang tersedia di perpustakaan. Rancangan urutan proses pengadaan persediaan pustaka dapat dilihat pada Gambar 13.

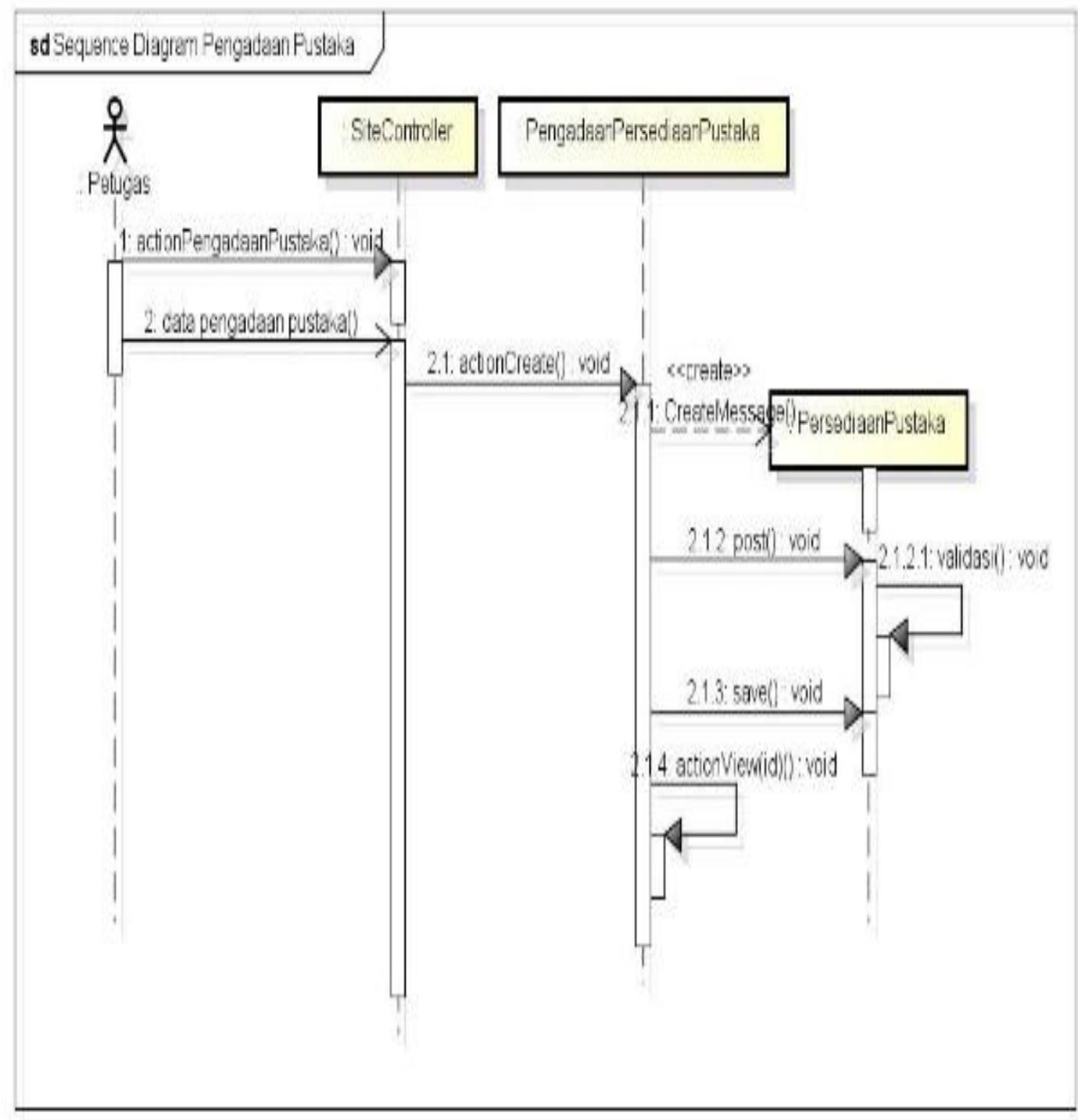

Gambar 13

Sequence Diagram Pengadaan Persediaan Pustaka

j. Penghapusan Persediaan Pustaka

Proses penghapusan persediaan pustaka digunakan untuk mencatat fisik pustaka yang tidak dapat digunakan karena berbagai hal. Pengapusan persediaan pustaka tidak menghapus data persediaan, akan tetapi hanya merubah data ketersediaan fisik pustaka menjadi tidak tersedia. Rancangan urutan proses penghapusan persediaan pustaka dapat dilihat pada Gambar 14. 


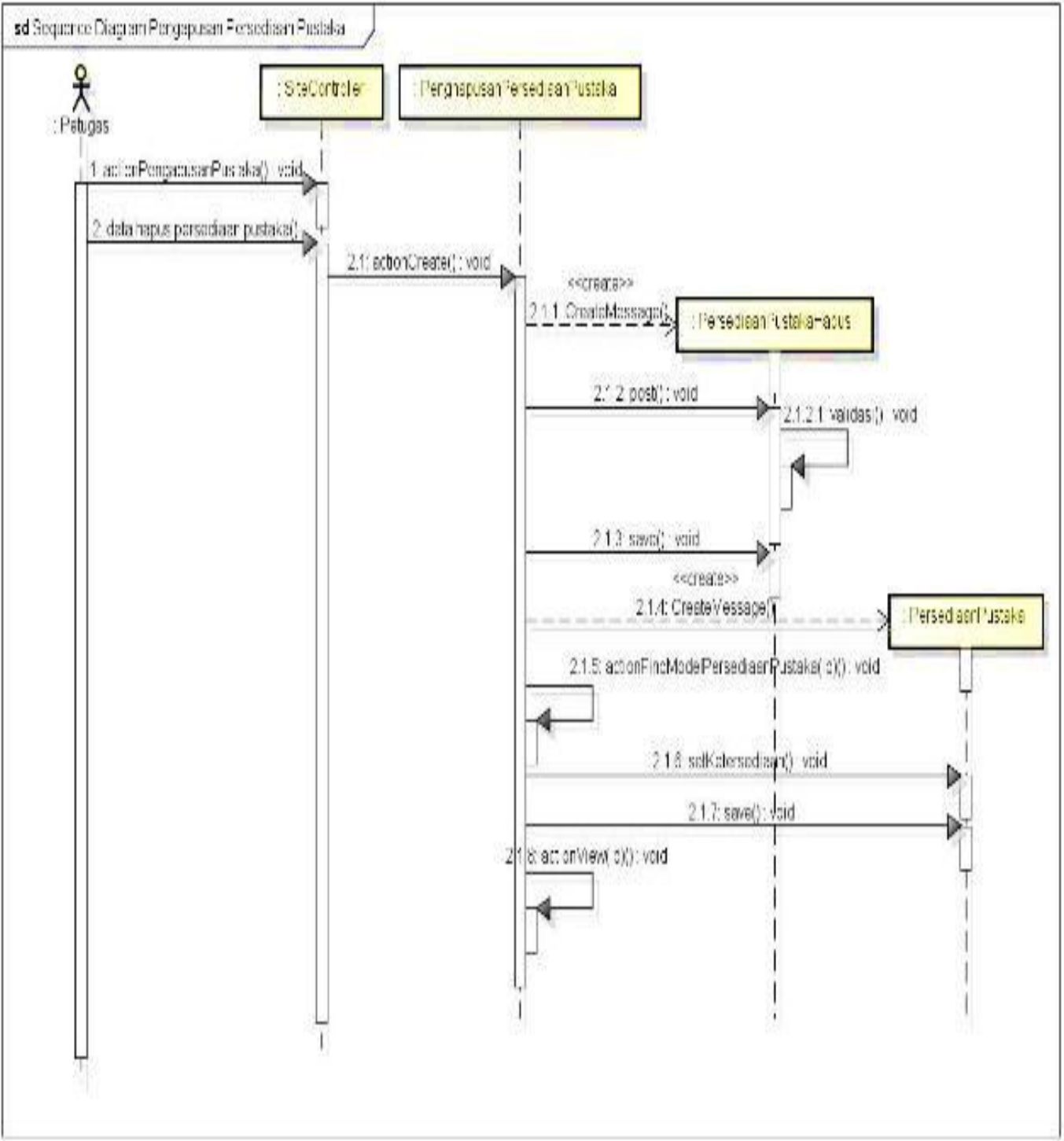

Gambar 14

Sequence Diagram Penghapusan Persediaan Pustaka

k. Transaksi Pinjam

Proses transaksi pinjam digunakan untuk mencatat data peminjaman pustaka oleh anggota. Sebelum data peminjaman tersimpan, akan dilakukan perhitungan tanggal pengembalian berdasarkan tanggal pinjam dan lama pinjam sesuai dengan tipe anggota. Setelah transaksi tersimpan, maka data status persediaan pustaka akan berubah menjadi keterangan bahwa pustaka sedang dipinjam. Rancangan urutan proses transaksi pinjam dapat dilihat pada Gambar 15. 


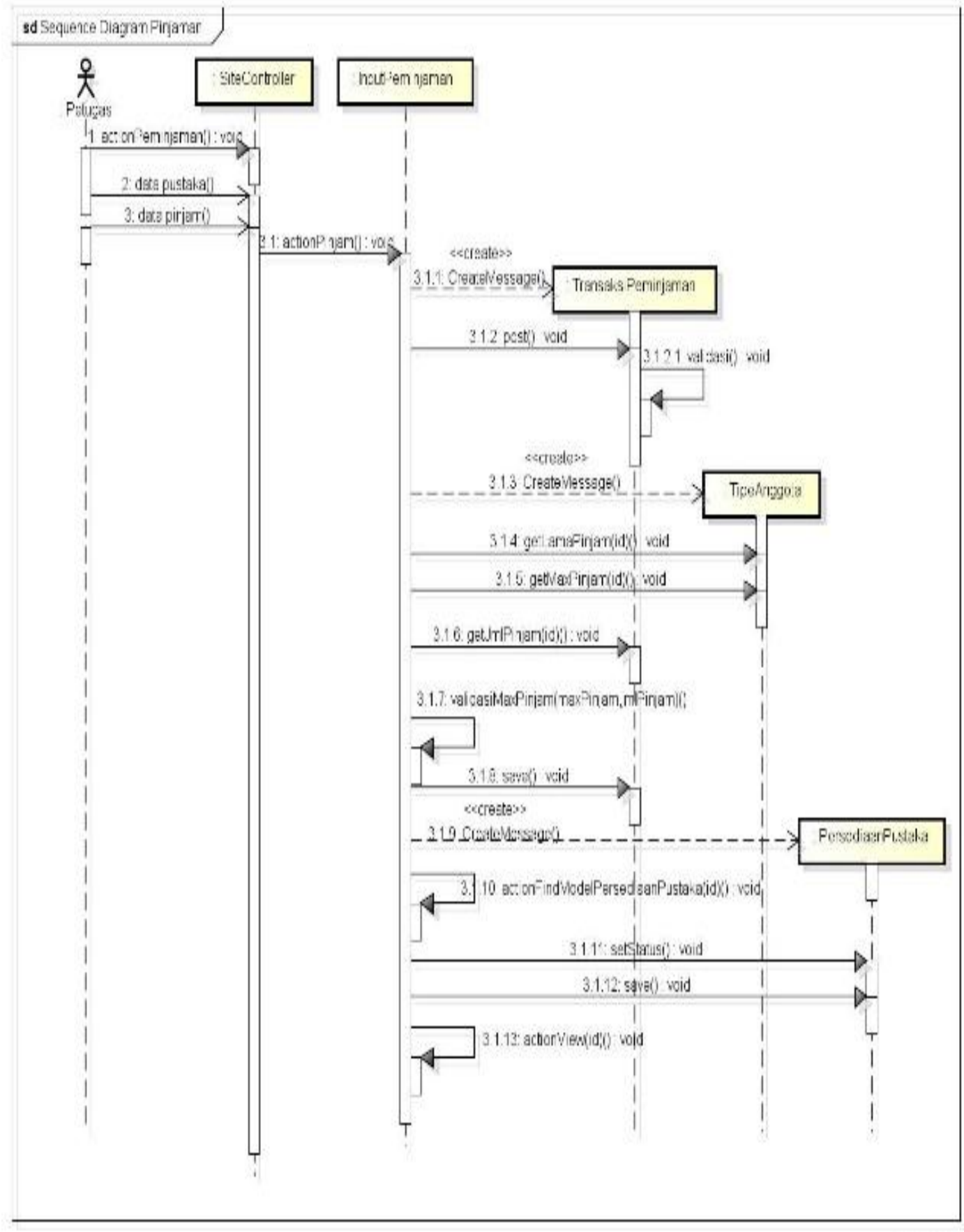

Gambar 15

Sequence Diagram Transaksi Pinjam

1. Transaksi Pengembalian

Proses transaksi pengembalian digunakan untuk merubah tanggal pustaka dikembalian pada data peminjaman. Pada proses ini, akan dilakukan perhitungan apakah tanggal pustaka dikembalikan lebih dari tanggal pengembalian. Jika tanggal pustaka dikembalikan lebih dari tanggal pengembalian, maka akan dilakukan perhitungan denda sesuai dengan tarif denda tipe anggota. Selanjutnya, denda yang diperhitungkan akan otomatis tercatat pada transaksi kas masuk. Rancangan urutan proses transaksi pinjam dapat dilihat pada Gambar 16. 


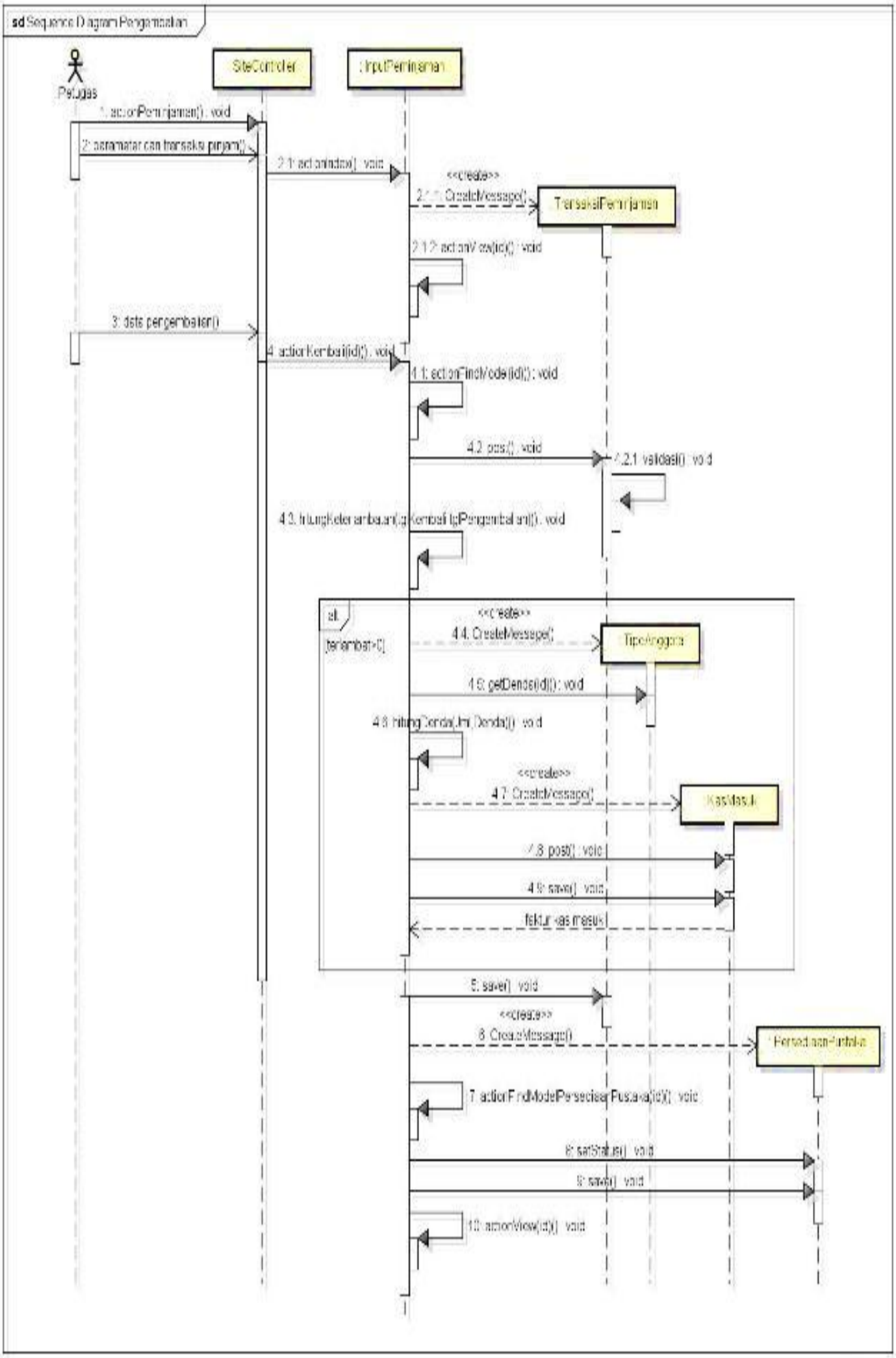

Gambar 16

Sequence Diagram Transaksi Pengembalian 
m. Trasaksi Kas Masuk

Proses transaksi kas masuk digunakan untuk mencatat pemasukan kas perpustakaan. Rancangan urutan proses transaksi kas masuk dapat dilihat pada Gambar 17.

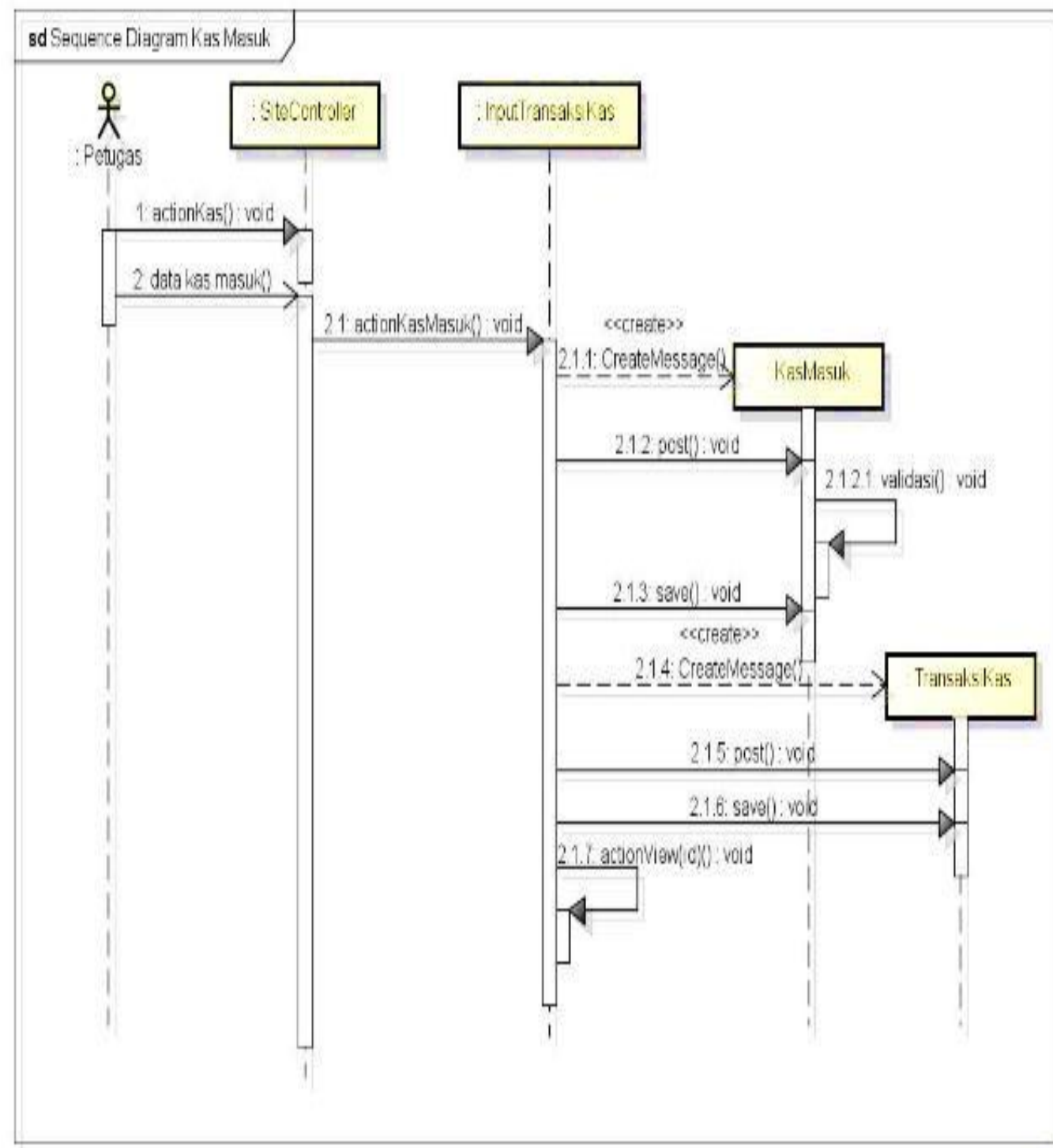

Gambar 17

powered by Aanhos

Sequence Diagram Transaksi Kas Masuk

n. Transaksi Kas Keluar

Proses transaksi kas keluar digunakan untuk mencatat pengeluaran kas perpustakaan untuk berbagai kebutuhan. Rancangan urutan proses transaksi kas keluar dapat dilihat pada Gambar 18. 


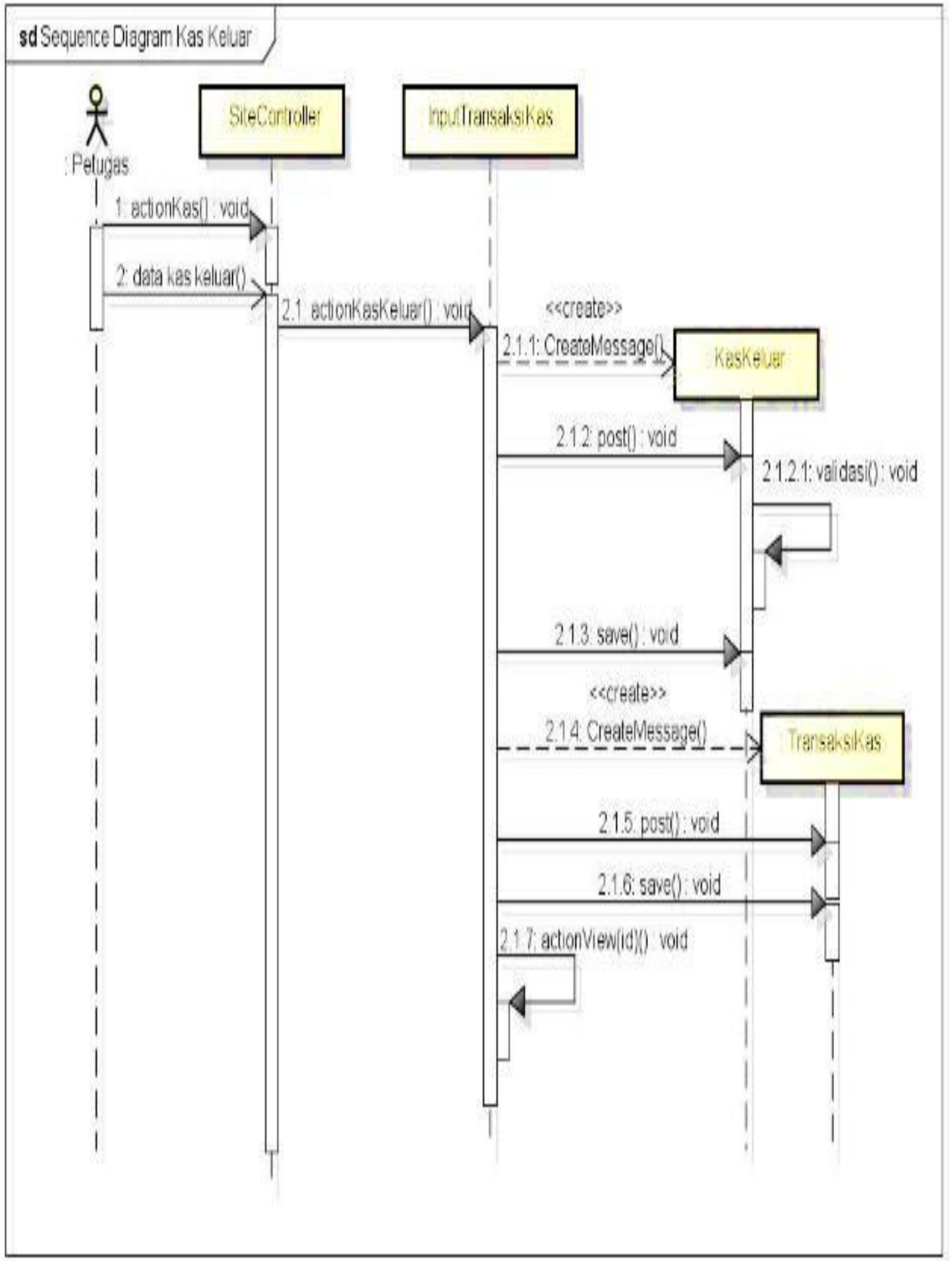

Gambar 18

Sequence Diagram Transaksi Kas Keluar

o. Tambah Staf

Proses penambahan staf digunakan untuk menambah data user yang mempunyai hak akses dalam mengelola data perpustakaan. Rancangan urutan proses penambahan staf dapat dilihat pada Gambar 19. 


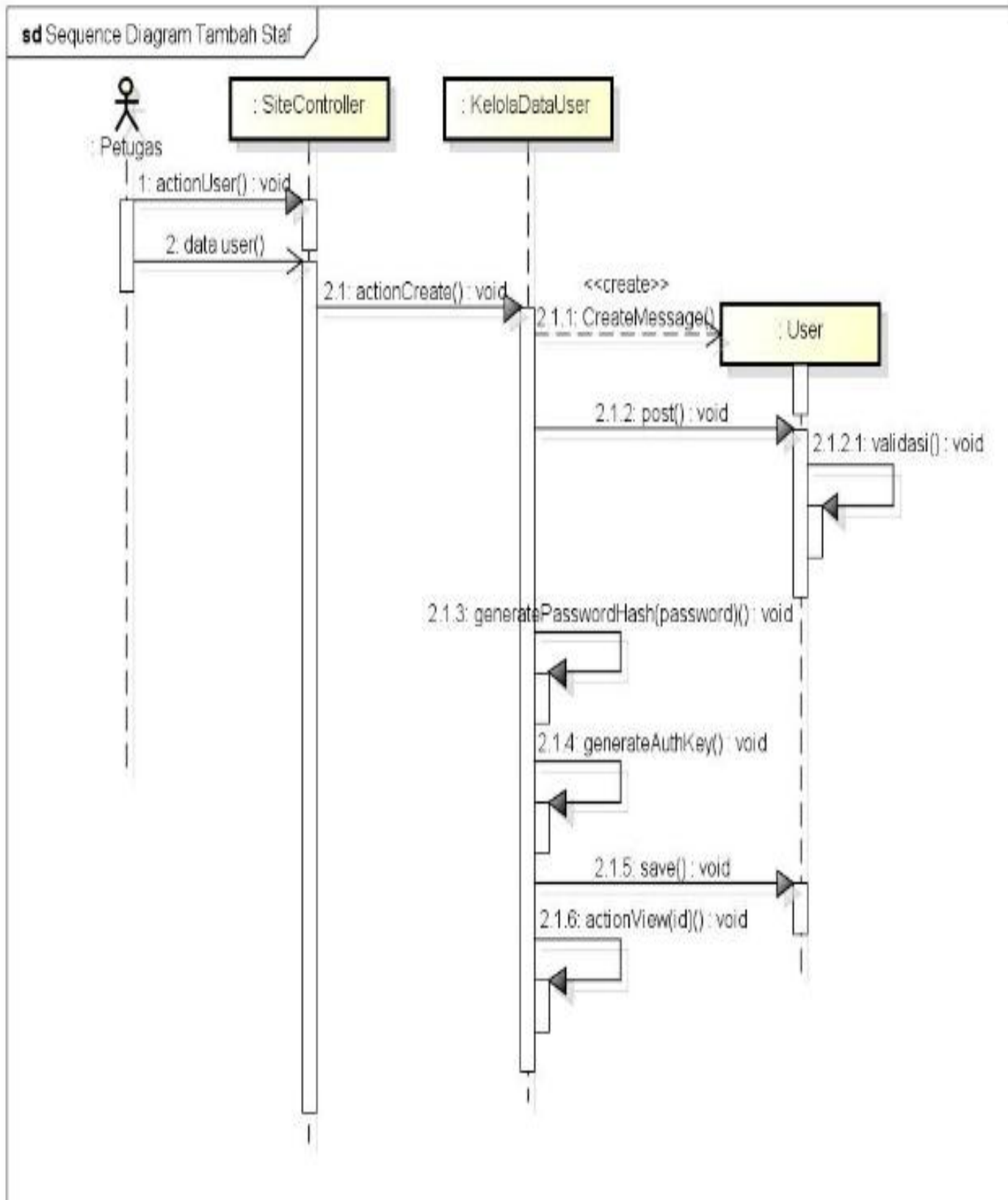

powered by Astah ie

Gambar 19

Sequence Diagram Tambah Staf

p. Edit Staf

Proses edit data staf digunakan untuk merubah data dan hak akses user dalam mengelola data perpustakaan. Rancangan urutan proses perubahan data staf dapat dilihat pada Gambar 20. 


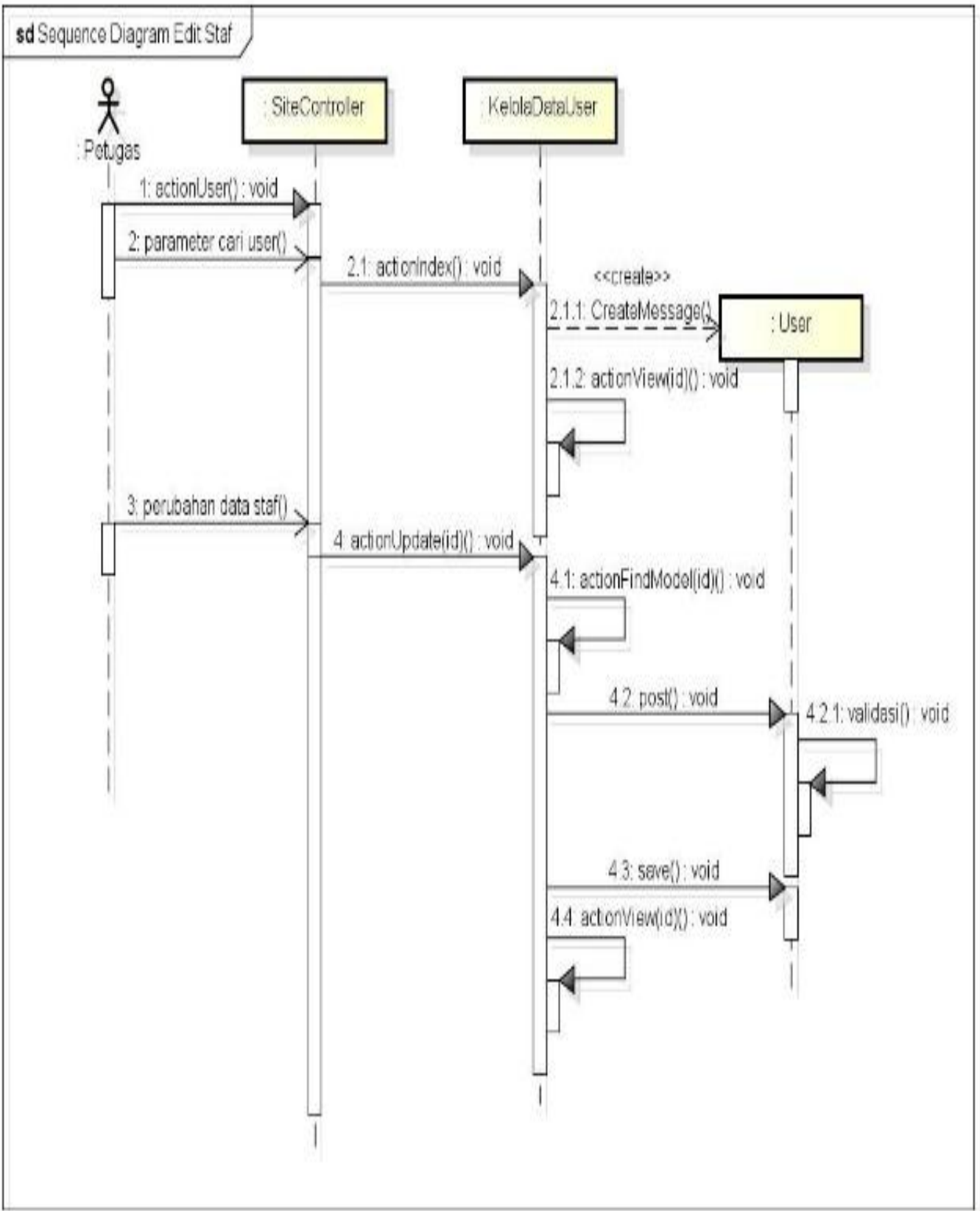

powered by Astahes

Gambar 20

Sequence Diagram Edit Staf

q. Hapus Staf

Proses hapus data staf digunakan untuk menghapus data user yang dapat mengelola data perpustakaan. Penghapusan data user hanya dapat dilakukan jika user tidak pernah melakukan atau terlibat dalam transaksi apapun. Rancangan urutan proses hapus data staf dapat dilihat pada Gambar 21. 


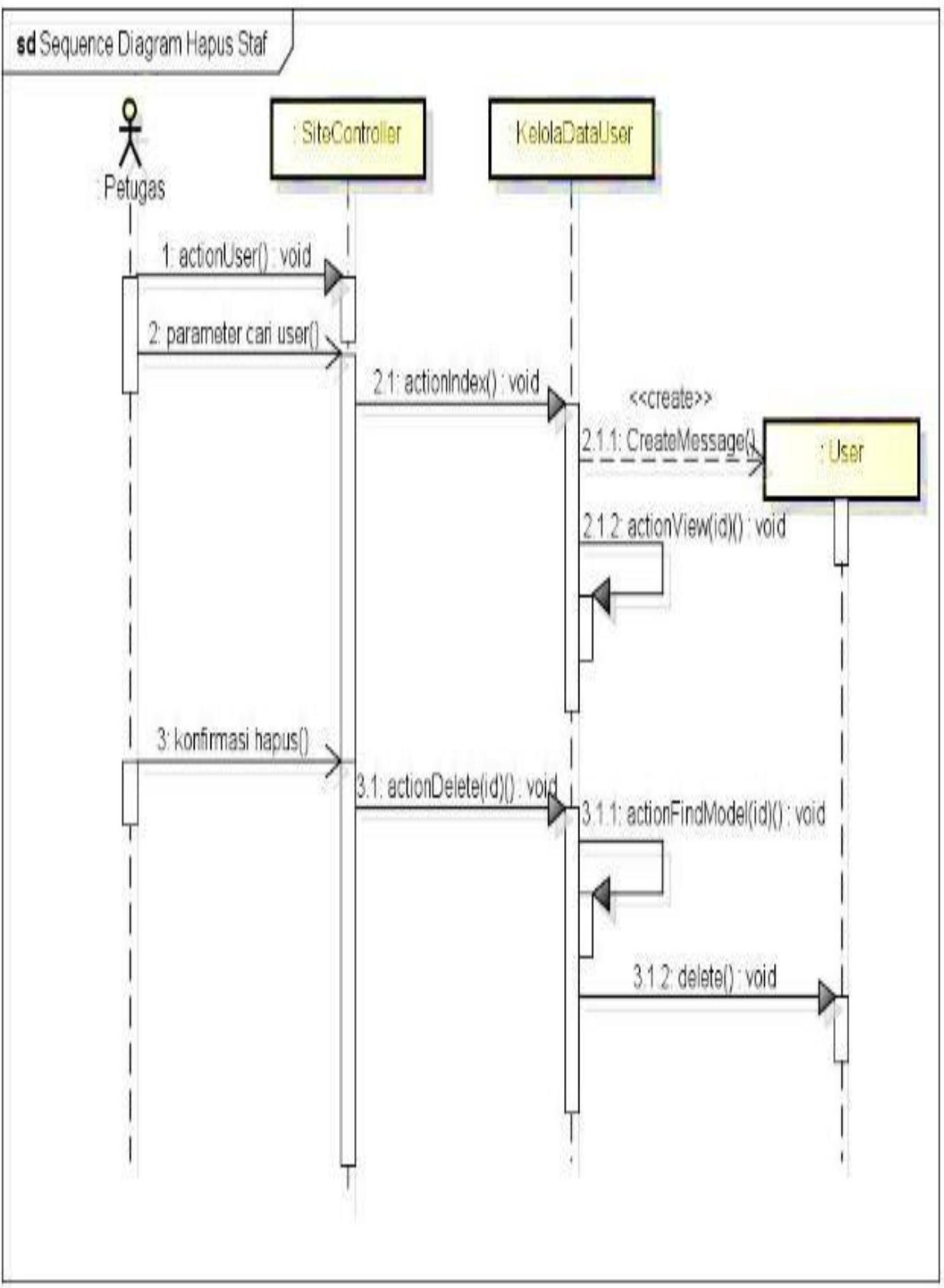

Gambar 21

Sequence Diagram Hapus Staf

r. Pengaturan Administrasi Anggota

Proses pengaturan administrasi anggota digunakan untuk memasukkan data lama pinjam, maksimal jumlah pinjam, biaya registrasi, dan denda untuk setiap tipe anggota. Rancangan urutan proses perubahan data staf dapat dilihat pada Gambar 22. 


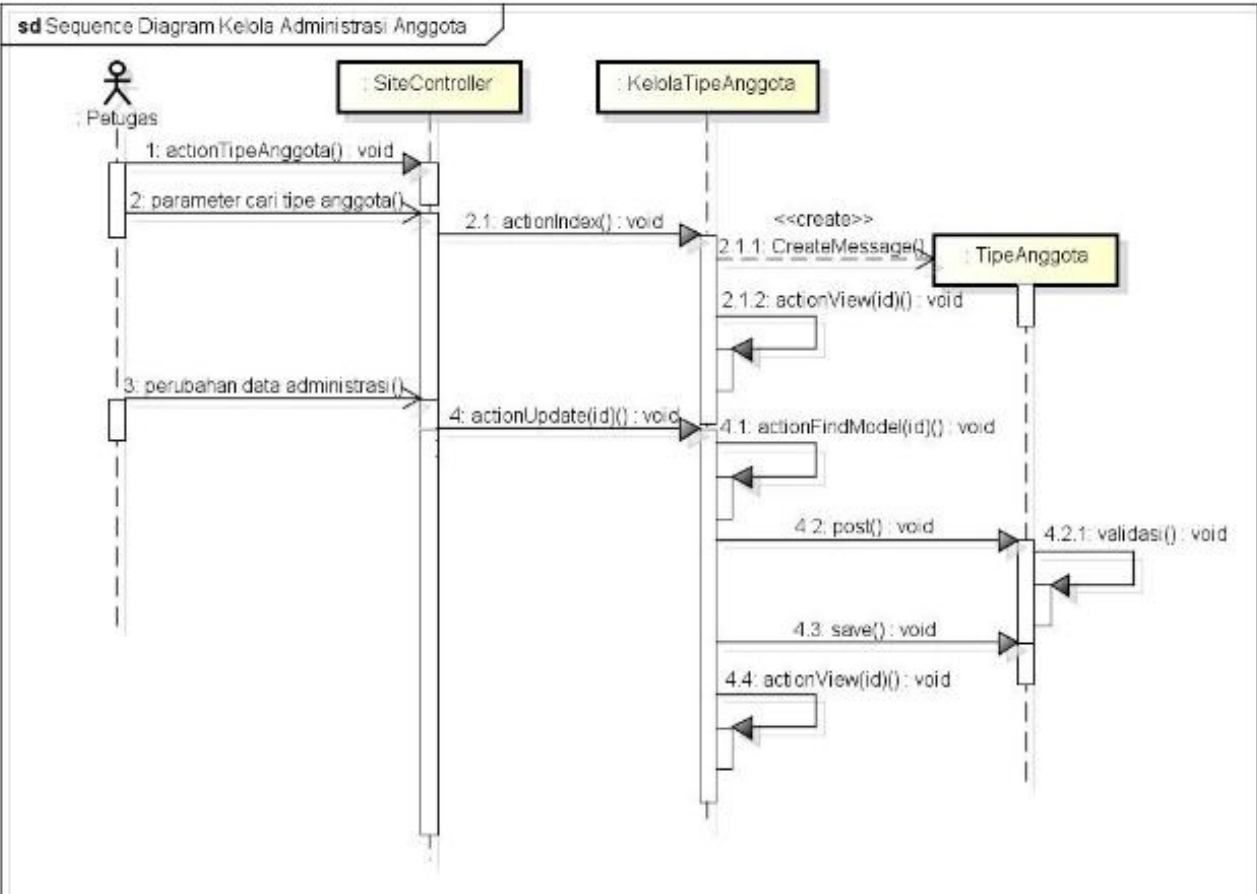

Gambar 22

powered by Astahâ

Sequence Diagram Pengaturan Administrasi Anggota

s. Cari Pustaka

Proses cari pustaka digunakan untuk mencari dan melihat rincian data pustaka, ketersediaan, dan status fisik pustaka, apakah tersedia atau sedang dalam proses pinjam oleh anggota. Rancangan urutan proses cari pustaka dapat dilihat pada Gambar 23.

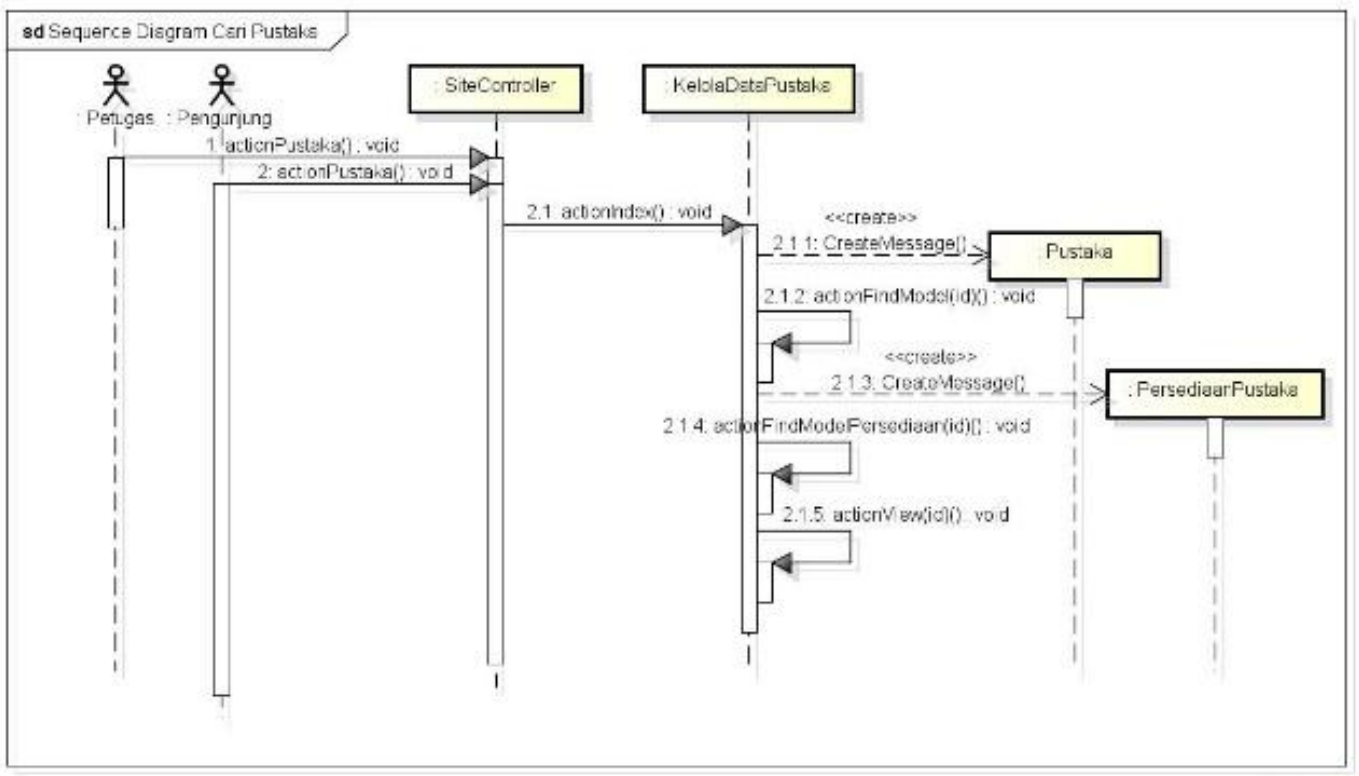

Gambar 23

Sequence Diagram Cari Pustaka 
t. Isi Buku Tamu

Proses isi buku tamu digunakan untuk mengisi data buku tamu oleh pengunjung perpustakaan. Buku tamu dapat digunakan untuk melihat jumlah pengunjung dan catatan dari pengunjung. Rancangan urutan proses isi buku tamu dapat dilihat pada Gambar 24.

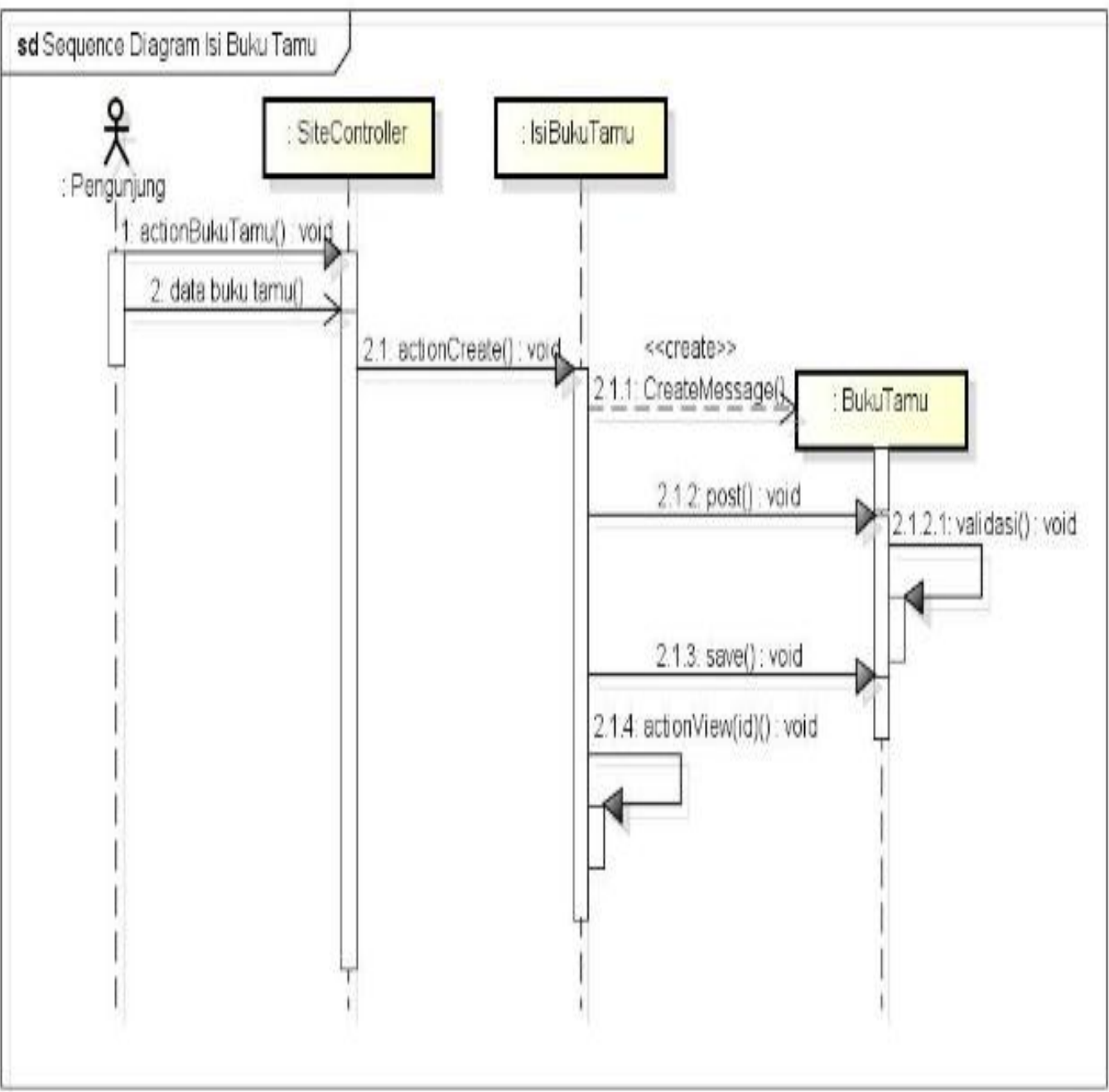

Gambar 24

Sequence Diagram Isi Buku Tamu

\section{Activity Diagram}

Rancangan activity diagram untuk melihat aktivitas sistem dari aplikasi yang akan dibangun, seperti yang dapat dilihat pada Gambar 25. 


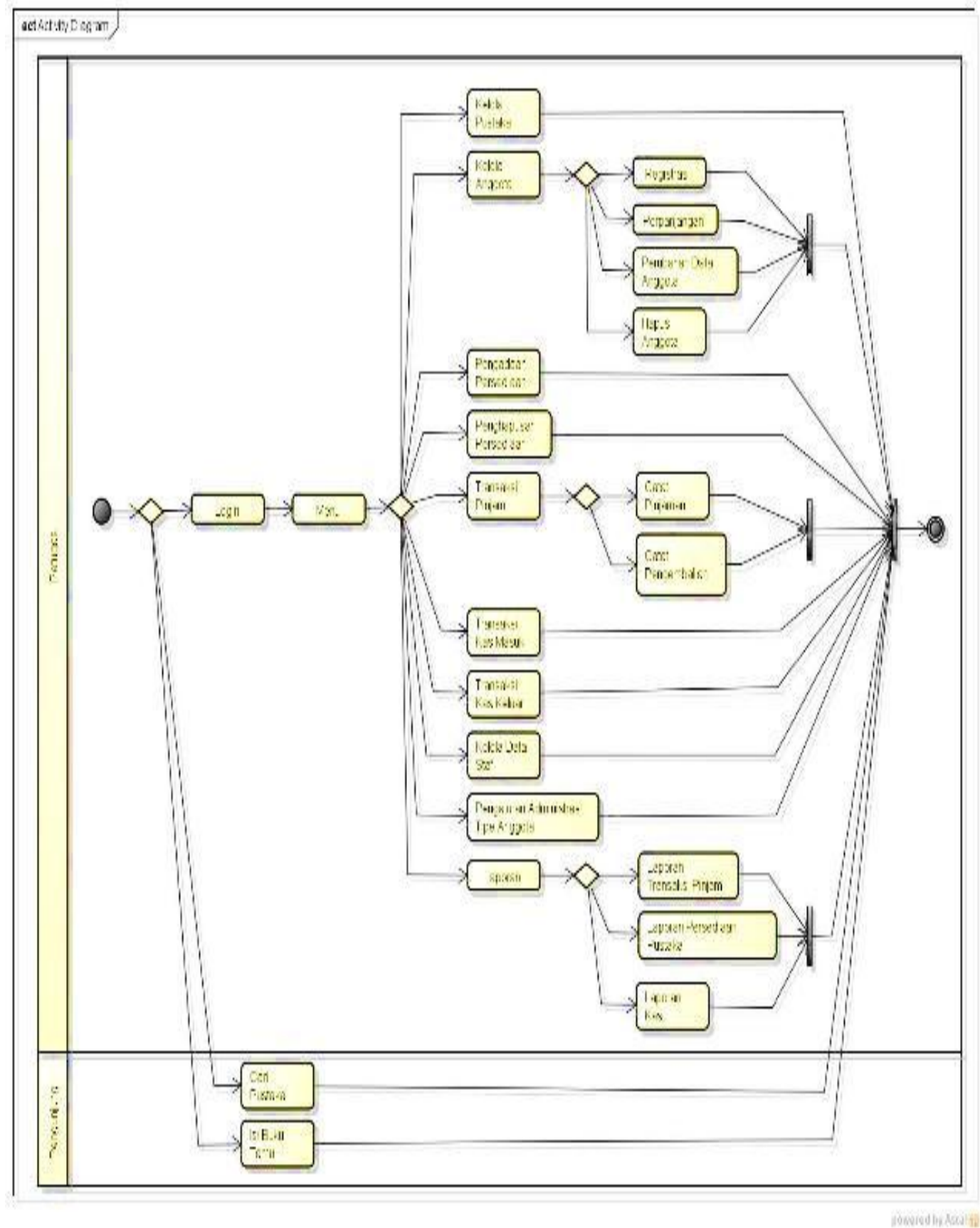

Gambar 25

Activity Diagram 
5. Rancangan Basis Data

Berikut adalah rancangan basis data dalam bentuk Logical Records Structure (LRS) seperti yang dapat dilihat pada Gambar 26 berdasarkan hasil analisis kebutuhan user.

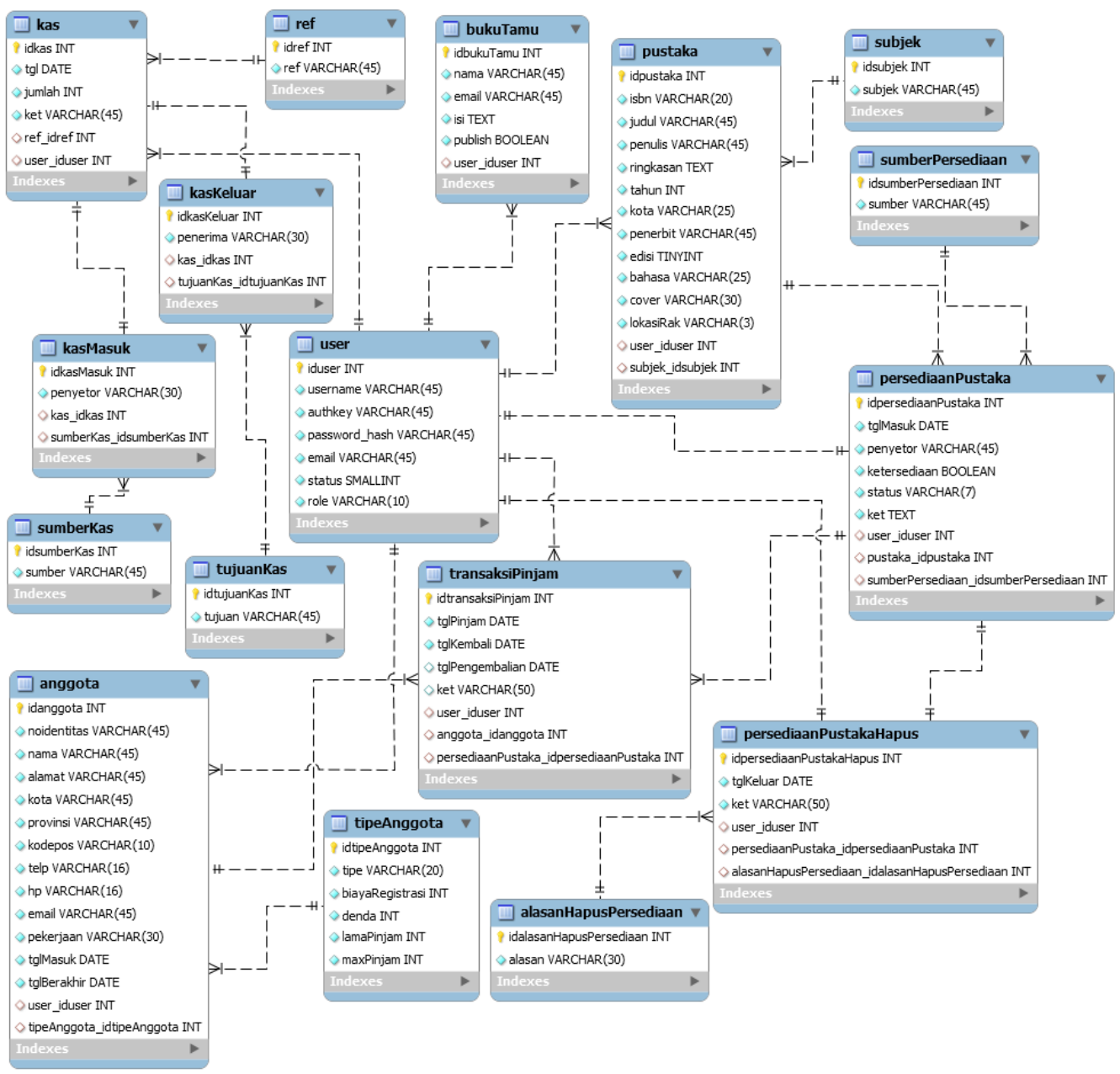

Gambar 26

LRS

6. Rancangan Dokumen Keluaran

Berikut adalah rancangan dokumen keluaran dari hasil pengolahan aplikasi:

a. Detail Pustaka

Halaman detail pustaka pada Gambar 27 menampilkan informasi pustaka, daftar persediaan termasuk informasi persediaan yang tersedia dan sedang dipinjam, serta informasi persediaan yang hilang, rusak, atau tidak tersedia secara permanen. 


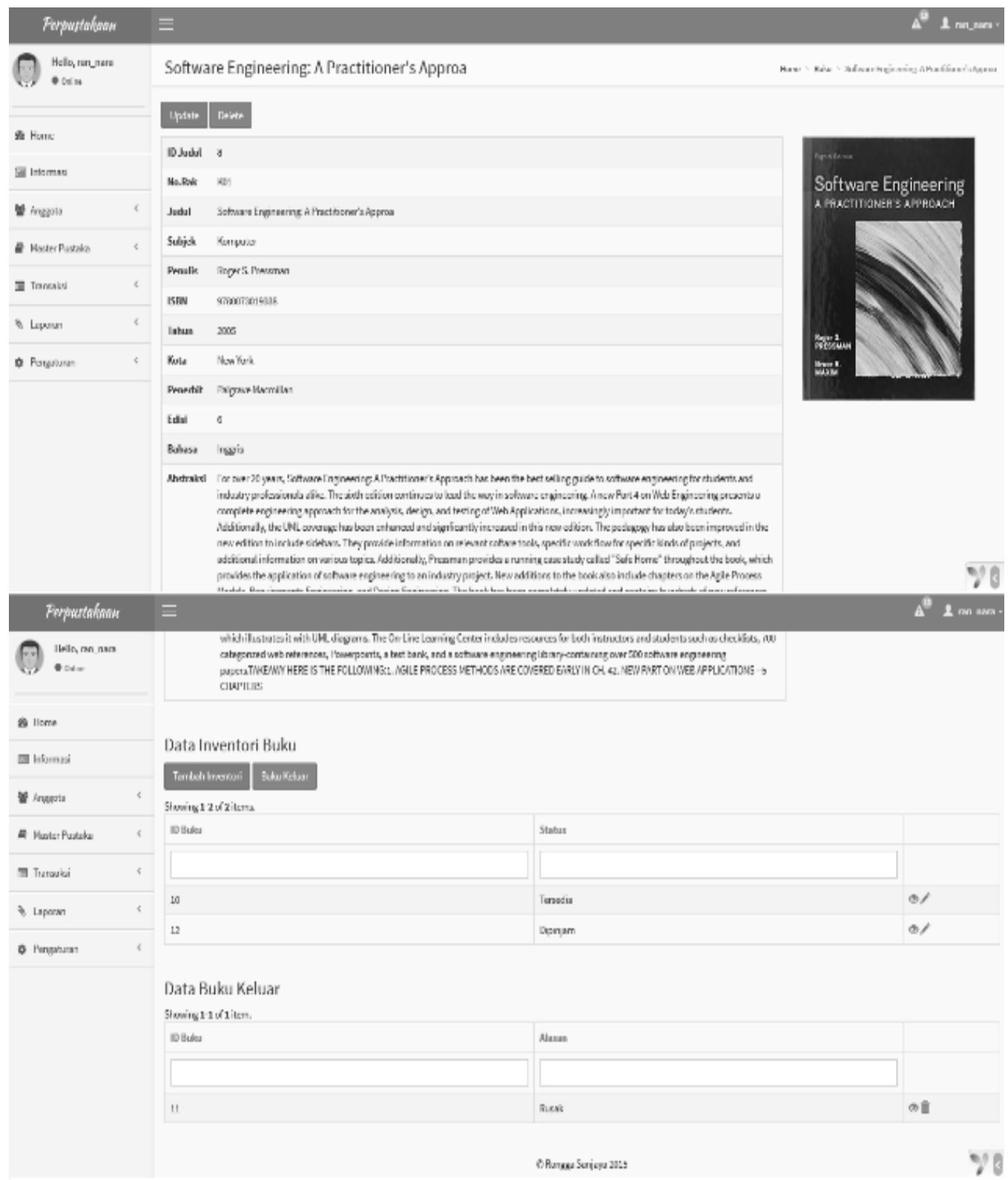

Gambar 27

Detail Pustaka

b. Laporan Transaksi Pinjam

Laporan transaksi pinjam pada Gambar 28 menampilkan informasi total peminjaman pustaka per subjek, transaksi pinjam yang sedang berjalan dan sudah dikembalikan, transaksi pinjam yang sudah dikembalikan dan pengembaliannya melewati batas tanggal pengembalian, dan transaksi pinjam yang sedang berjalan tetapi sudah melewati batas tanggal pengembalian. 
SISTEM INFORMASI PERPUSTAKAAN

Laporan Transaksi Pinjam Periode Bulan Maret 2015 Transaksi Pinjam Per Subjek

\begin{tabular}{|l|l|l|}
\hline Subjek & Jumlah & Prosentase \\
\hline Akuntansi & 1 & $17 \%$ \\
\hline Ekonomi & 2 & $33 \%$ \\
\hline Komputer & 3 & $50 \%$ \\
\hline
\end{tabular}

Transaksi Pinjam Berjalan

\begin{tabular}{|l|l|}
\hline Subjek & Jumlah \\
\hline Akuntansi & 1 \\
\hline Komputer & 1 \\
\hline & \\
Transaksi Pinjam Selesai & \\
\hline Subjek & \multicolumn{1}{|l|}{} \\
\hline Ekonomi & Jumlah \\
\hline
\end{tabular}

Transaksi Pinjam Lewat Batas Tanggal Pengembalian Berjalan

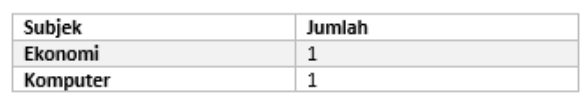

Transaksi Pinjam Lewat Batas Tanggal Pengembalian Selesai

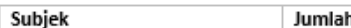

\begin{tabular}{|l|l|}
\hline Subjek & Jum \\
\hline Komputer & 1 \\
\hline
\end{tabular}

Gambar 28

Laporan Transaksi Pinjam

c. Laporan Persediaan Pustaka

Laporan transaksi persediaan pustaka pada Gambar 29 menampilkan informasi total persediaan pustaka yang tersedia, sumber pengadaan, dan jumlah persediaan pustaka yang sudah dihapus.

SISTEM INFORMASI PERPUSTAKAAN

Laporan Persediaan Pustaka Periode Bulan Maret 2015

Persediaan Pustaka Per Subjek

\begin{tabular}{|l|l|}
\hline Subjek & Jumlah \\
\hline Akuntansi & 2 \\
\hline Ekonomi & 2 \\
\hline Komputer & 5 \\
\hline
\end{tabular}

Sumber Persediaan Pustaka

\begin{tabular}{|l|l|}
\hline Sumber & Jumlah \\
\hline Pengadaan Perpustakaan & 9 \\
\hline Sumbangan Mahasiswa & 2 \\
\hline Penggantian Kehilangan & 0 \\
\hline
\end{tabular}

Penghapusan Persediaan Pustaka

\begin{tabular}{|l|l|}
\hline Alasan & Jumlah \\
\hline Hilang & 0 \\
\hline Rusak & 2 \\
\hline
\end{tabular}

Ketersediaan Pustaka

\begin{tabular}{|l|l|}
\hline Ketersediaan & Jumlah \\
\hline Tersedia & 3 \\
\hline Dipinjam & 6 \\
\hline
\end{tabular}

Gambar 29

Laporan Persediaan Pustaka d. Laporan Kas

Laporan kas pada Gambar 30 menampilkan informasi sumber penerimaan dan penggunaan kas, serta saldo akhir kas perpustakaan.

SISTEM INFORMASI PERPUSTAKAAN

Laporan Kas Periode Bulan Maret 2015

\begin{tabular}{l|l|}
\hline Kas Masuk & \\
\hline Sumber & Jumlah \\
\hline Modal & 100000 \\
\hline Registrasi Anggota & 35000 \\
\hline Perpanjangan Anggota & 0 \\
\hline Denda Pinjam & 1000 \\
\hline Penggantian Kehilangan & 0 \\
\hline Lain-lain & 0 \\
\hline & \\
\hline Jumlah Kas Masuk & 136000 \\
\hline & \\
\hline Kas Keluar & \\
\hline Tujuan & Jumlah \\
\hline Setoran Rutin & 50000 \\
\hline Penggantian Kehilangan & 0 \\
\hline Pengadaan Pustaka & 0 \\
\hline Biaya Koran & 5000 \\
\hline Biaya Majalah & 10000 \\
\hline Operasional & 20000 \\
\hline Inventaris & 0 \\
\hline & \\
\hline Jumlah Kas Keluar & $\mathbf{8 5 0 0 0}$ \\
\hline & \\
\hline Saldo Akhir & $\mathbf{5 1 0 0 0}$ \\
\hline &
\end{tabular}

Gambar 30

Laporan Kas

\section{PENUTUP}

\section{Kesimpulan}

Perancangan sistem informasi perpustakaan dengan menggunakan pola Model-View-Controller (MVC) dapat memudahkan pengembangan aplikasi dengan adanya pemisahan blok-blok lingkup kerja. Perubahan terhadap salah satu komponen dapat dilakukan tanpa merubah keseluruhan sistem yang dibangun, sehingga sangat mendukung pengembangan sistem dengan metode incremental. Rancangan aplikasi yang dibangun dapat memudahkan petugas perpustakaan dalam mengelola berbagai aktivitas dan meningkatkan kinerja petugas perpustakaan. Penggunaan teknologi website memudahkan penambahan perangkat kerja tanpa harus melakukan konfigurasi aplikasi karena website dapat langsung diakses oleh media yang terkoneksi dalam jaringan. Output yang dihasilkan berupa laporan masing-masing komponen perpustakaan 
serta laporan kas perpustakaan, yang dapat dijadikan informasi dalam pengambilan keputusan.

\section{REFERENSI}

Muzakir, Ari. 2014. Implementasi Manajemen Perpustakaan menggunakan Framework Codeigniter (CI) Dengan Teknik Hierarchical model-view-controller (HMVC). Seminar Nasional Sains dan Teknologi Informasi (SeNASTI).

Pebrianto, S. 2012. Pembangunan Sistem Informasi Perpustakaan pada Perpustakaan Umum Kabupaten Pacitan. Jurnal Speed 13 FTI UNSA. 9 (2). 232-236.

Pressman, R. 2001. Software engineering: a practitioner's approach. Edisi 5. McGraw-Hill. New York-USA.

Siahaan, F.O.P. 2013. Standardization Online Accounting System Based on Information Technology. International Journal of Business and Social Science. 4 (12). 270-276.

Yii Software LLC. About Yii. http://www.yiiframework.com/about /. Diakses tanggal 19 Februari 2015. 